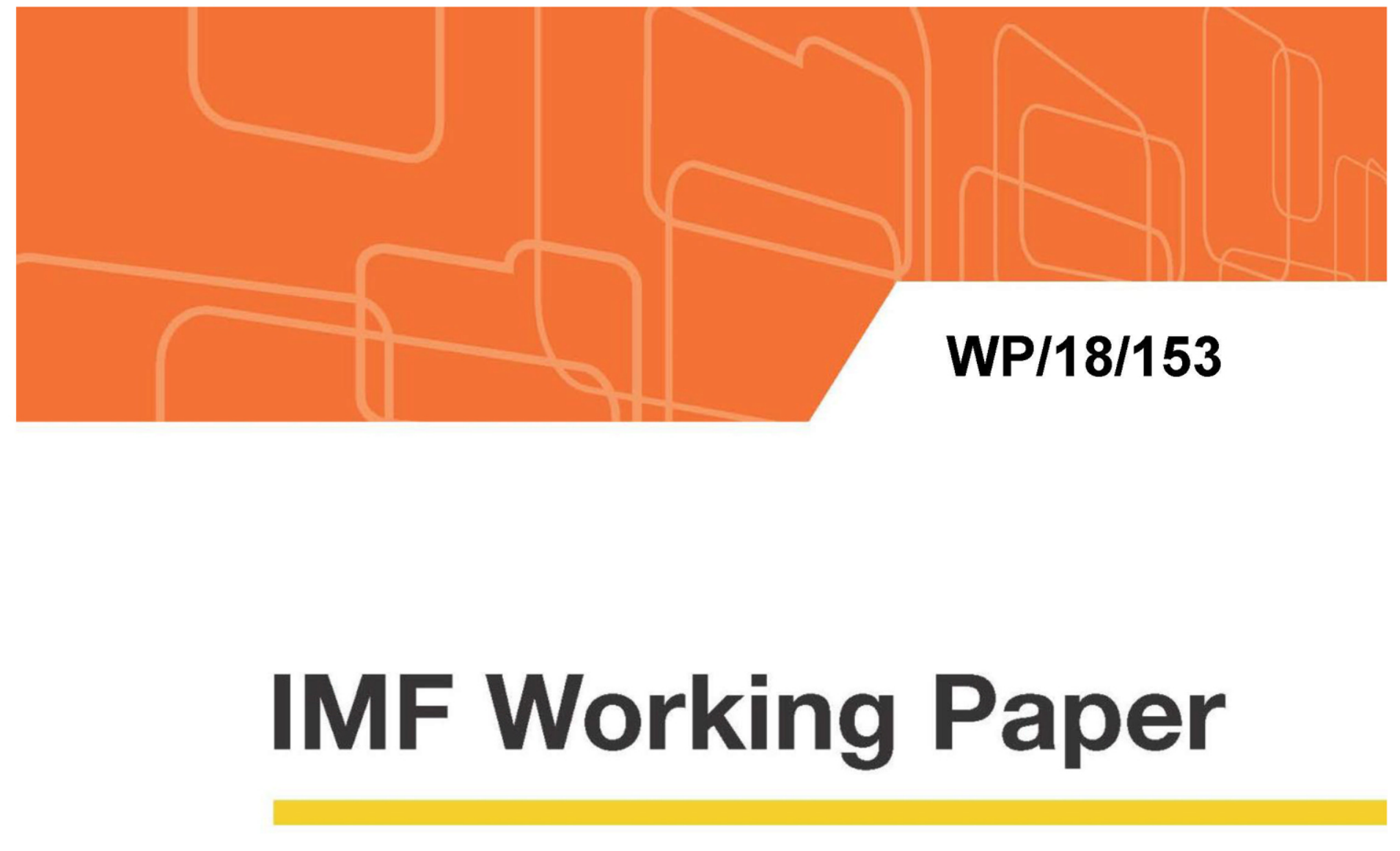

\title{
Commodity Price Movements and Banking Crises
}

by Markus Eberhardt and Andrea Presbitero

IMF Working Papers describe research in progress by the author(s) and are published to elicit comments and to encourage debate. The views expressed in IMF Working Papers are those of the author(s) and do not necessarily represent the views of the IMF, its Executive Board, or IMF management. 


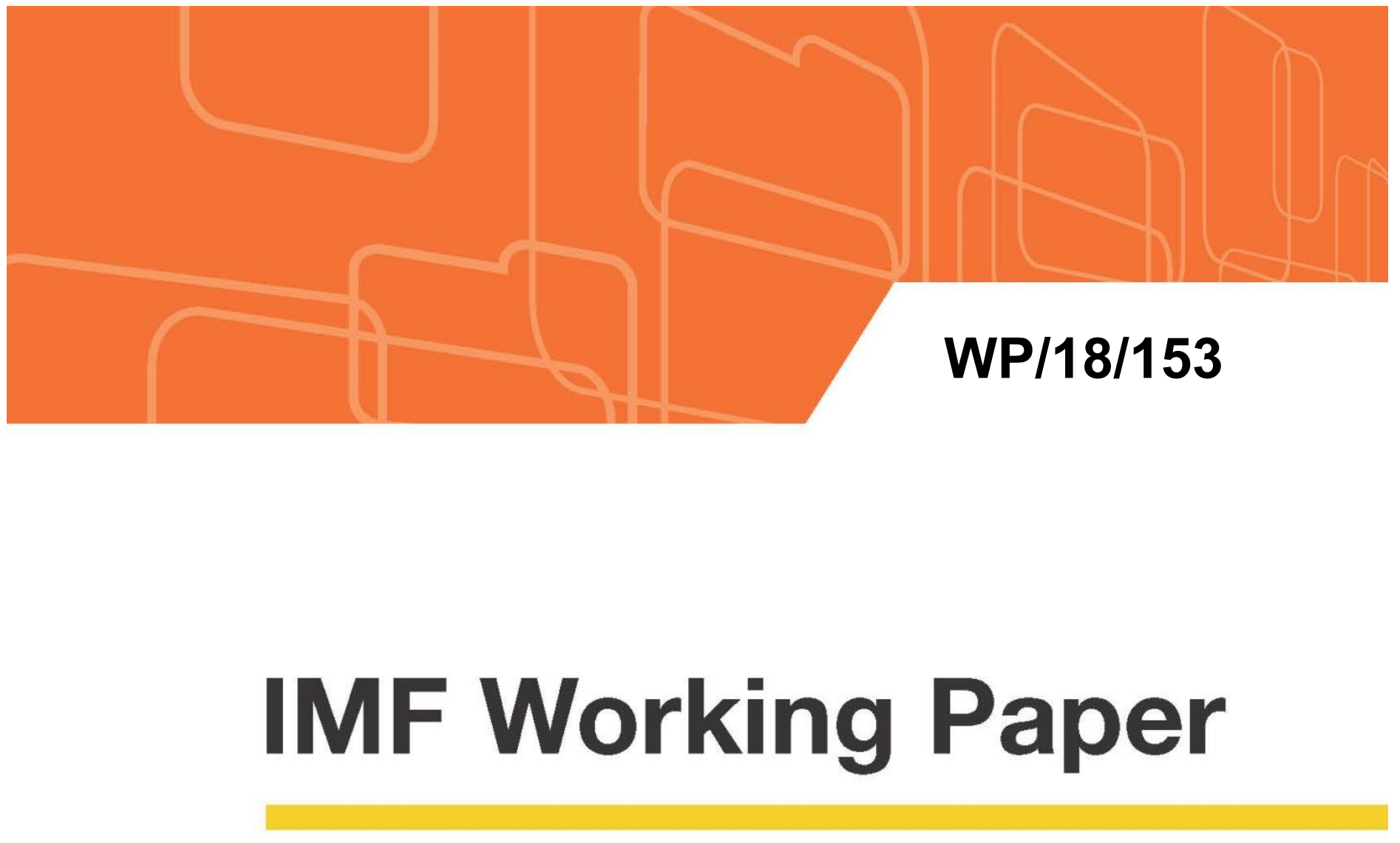

\section{Commodity Price Movements and Banking Crises}

by Markus Eberhardt and Andrea Presbitero

IMF Working Papers describe research in progress by the author(s) and are published to elicit comments and to encourage debate. The views expressed in IMF Working Papers are those of the author(s) and do not necessarily represent the views of the IMF, its Executive Board, or IMF management. 


\title{
IMF Working Paper
}

\author{
Research Department
}

Commodity Price Movements and Banking Crises ${ }^{1}$

Prepared by Markus Eberhardt, Andrea Presbitero

Authorized for distribution by Maria Soledad Martinez Peria

June 2018

\section{IMF Working Papers describe research in progress by the author(s) and are published to elicit comments and to encourage debate. The views expressed in IMF Working Papers are those of the author(s) and do not necessarily represent the views of the IMF, its Executive Board, or IMF management.}

\begin{abstract}
We develop an empirical model to predict banking crises in a sample of 60 low-income countries (LICs) over the 1981-2015 period. Given the recent emergence of financial sector stress associated with low commodity prices in several LICs, we assign price movements in primary commodities a key role in our model. Accounting for changes in commodity prices significantly increases the predictive power of the model. The commodity price effect is economically substantial and robust to the inclusion of a wide array of potential drivers of banking crises. We confirm that net capital inflows increase the likelihood of a crisis; however, in contrast to recent findings for advanced and emerging economies, credit growth and capital flow surges play no significant role in predicting banking crises in LICs.
\end{abstract}

JEL Classification Numbers: F34, G01, Q02, G21, O19

Keywords: Banking crisis; Commodity prices; Early warning system; Low-income countries Authors’ E-Mail Addresses: Markus.Eberhardt@nottingham.ac.uk, apresbitero@imf.org

\footnotetext{
${ }^{1}$ This research is part of a project on Macroeconomic Research in Low-Income Countries (project id: 60925) supported by the UK's Department for International Development, and the first draft was prepared when Eberhardt was a Visiting Economist at the IMF. The views expressed in this paper are those of the authors and do not necessarily represent those of the IMF, IMF policy, or of DfID. We wish to thank Rupa Duttagupta, numerous IMF colleagues, and participants at the Georgetown Center for Economic Research Biennial Conference (Washington DC, 2017) and seminars at the IMF for helpful comments and suggestions. We also thank Bertrand Gruss and Fabian Valencia for kindly sharing data on commodity prices and updated data on systemic banking crises, respectively. The usual disclaimers apply.
} 


\section{Contents}

1 Introduction $\quad \underline{3}$

2 Data and Descriptive Analysis $\quad \underline{8}$

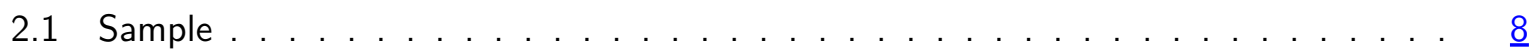

2.2 Variable Construction and Sources ................. $\underline{8}$

2.3 Variable Transformation . . . . . . . . . . . . . . . 11

2.4 Event Analysis . . . . . . . . . . . . . . . . . . . . . . 12

3 Empirical Model and Implementation $\underline{15}$

4 Results and Discussion $\quad \underline{17}$

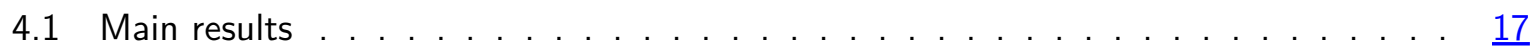

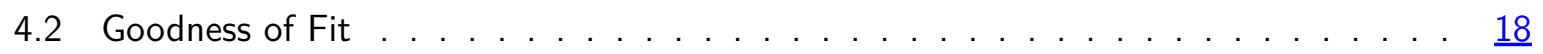

4.3 Robustness of the Baseline . . . . . . . . . . . . . . . . . 19

4.4 The Role of Leverage . . . . . . . . . . . . . . . . . . . 21

4.5 Capital Inflows Bonanza . . . . . . . . . . . . . . . . . 22

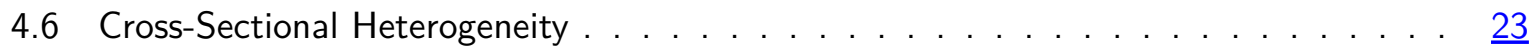

5 Concluding Remarks $\quad \underline{24}$

A Data Sources and Sample Makeup

B Additional Figures

C Additional Regression Results 


\section{Introduction}

After a period of widespread financial instability in the 1980s and 1990s, mostly concentrated among commodity exporters, only a handful of low-income countries (LICs) have been hit by systemic banking crises over the past two decades. A number of factors have likely contributed to this state of affairs, including an extended period of sustained economic growth, financial deepening and favorable external conditions, most notably a protracted period of stable and high commodity prices (Figure 1). Since 2014, however, an increasing number of economies have been experiencing financial stress, as evidenced by declining bank profitability and a sharp deterioration in bank asset quality (International Monetary Fund, 2017)—a development consistent with the view that graduation from banking crises has so far proven illusive (Reinhart and Rogoff, 2013). While many country-specific factors play a role in these developments, the sharp and persistent decline of commodity prices is a common feature of these recent episodes of financial stress: in the period from July 2014 to June 2017 three quarters of the primary commodity price series collected by the IMF declined, more than half by $10 \%$ or more. ${ }^{1}$ The picture looks similarly bleak when studying commodity price forecasts to $2022 .^{2}$

Financial deepening, a better regulatory framework, greater financial integration, and increasing economic diversification are all elements suggesting that LICs are now structurally different from what they were in the 1980s and early 1990s (Bluedorn et al., 2014). If this were the case, there would be limited scope to learn from the past to predict financial instability in the future. However, it could very well be that countries are still vulnerable to similar factors as they were in the past (Reinhart and Rogoff, 2013). We argue that vulnerability to external factors-and in particular commodity prices-is still a pressing issue for many developing countries and the fact that this vulnerability to date has not translated into crisis episodes could mostly be due to a commodity super-cycle: stable and high commodity prices over the past two decades. The recent "low for long" scenario in commodity prices (International Monetary Fund, 2015) could however reverse this trend and, in fact, is already showing severe consequences in a number of countries.

Motivated by these developments, and to discriminate between the two hypotheses- the lim-

\footnotetext{
${ }^{1}$ Top-10 export earners for our LIC sample such as crude oil $(-56 \%)$, cocoa $(-31 \%)$, shrimp $(-31 \%)$, sugar $(-27 \%)$, and copper $(-20 \%)$ were among those with the most substantial price drops.

${ }^{2}$ When we adopt IMF price forecasts we find that $82 \%$ of primary commodity price series are predicted to experience negative growth between 2014 (observed price) and 2022 (forecast), with almost $60 \%$ of series declining by double digits percentage points.
} 
ited number banking crisis events due to graduation from vulnerability or the positive effect of the commodity super-cycle — this paper revisits the literature on the drivers of banking crises, zooming in on the experience of low-income countries and on the role of commodity prices alongside, more broadly, external factors. In fact, while it is true that LICs traditionally relied on official financing, since the early 2000s non-official (private) capital inflows to low-income developing economies have increased markedly and in the last decade gross flows have been comparable to those in emerging markets (Araujo et al., 2017). ${ }^{3}$

The specific economic and financial structure of many low-income countries requires the use of a different empirical framework, given that key drivers of financial instability identified in advanced economies and emerging markets are less likely to be relevant in LICs. Namely, while the literature focused on the former group of countries has reached near-consensus on the dominant role played by credit booms (Schularick and Taylor, 2012; Bordo and Meissner, 2016), the relatively limited size of the financial sector and an ongoing process of financial deepening are likely to minimize the incidence of boom-and-bust episodes in the latter. ${ }^{4}$ On the other hand, LICs are extremely vulnerable to external shocks and commodity prices are one of the most important factors driving output fluctuations (Mendoza, 1997; Deaton, 1999; Bleaney and Greenaway, 2001; Raddatz, 2007). In recent analysis Fernández et al. (2017) show that since the 1960s global shocks account for about one quarter of output fluctuations in LICs; this share is comparable to that in richer economies and, with the financialization of commodity markets, has significantly increased over the past decade and a half.

Commodity price fluctuations do not only affect the real economy, but also the financial sector. Agarwal et al. (2017) show that a fall in commodity prices reduces bank lending, an effect which is stronger for commodity exporters and driven by commodity price busts. More generally, a drop in commodity prices could lead to financial instability and crises through different channels, which are especially pertinent in commodity-exporting LICs: first, lower prices translate into reduced revenues for exporting firms, which find it more difficult to service their debt obligations, with potential negative

\footnotetext{
${ }^{3}$ See also Figure B-2 in the Appendix.

${ }^{4} \mathrm{~A}$ simple glance at the evolution of private credit over GDP in LICs is more consistent with a steady pattern of financial deepening, than with the presence of credit cycles and well-defined credit booms and busts; see Figure B-1 in the Appendix. A notable exceptions is the 2009 banking crisis in Nigeria, where domestic credit to the private sector increased from 13 percent of GDP in 2002-2006 to 38 percent in 2009.
} 
effects on banks asset quality. Second, to the extent that they induce a surge in bank withdrawals, declining commodity prices could impact on bank funding. Third, if the drop in commodity prices puts pressures on the public sector, the latter could start running arrears to supplier and contractors, triggering second round effects on bank balance sheets. ${ }^{5}$

An event analysis conducted on the 11-year window around banking crisis episodes-in the spirit of Gourinchas and Obstfeld (2012) — provides a set of descriptive findings which support these arguments and motivate our analysis. Specifically, while in our sample of low-income countries there is no evidence of a boom and bust cycle in private credit, banking crises are preceded by declining commodity prices.

In light of these considerations, we develop an early warning system (EWS) for banking crises on a sample of 60 LICs-over the 1981-2015 period-considering a large set of domestic and external variables as potential leading indicators of systemic banking crises, as defined by Laeven and Valencia (2013). Our preferred empirical results derive from a random effects logit model augmented with country-specific means of all covariates (also known as the 'correlated random effects' model) following an approach which goes back to Mundlak (1978) and Chamberlain (1982). This enables us to maintain the full sample of 60 countries, including those which never experienced a crisis episode, while still estimating parameter coefficients that can be interpreted as 'within-country' estimates: determining the factors that avoid crises is just as important as determining those which trigger them, thus an empirical framework which excludes any country which never experienced a banking crisis would seem a questionable starting point for analysis. The adoption of a RE-Mundlak model avoids this potential error (see Caballero, 2016, for a more technical treatment).

Our results indicate that commodity prices are a key driver of the likelihood of banking crises in LICs and their inclusion in the model significantly increases its predictive power. More specifically, in our preferred specification a one standard deviation reduction in the annual change in aggregate commodity prices is associated with a 1.4 percentage point increase in the probability of a crisis. This effect is primarily driven by more integrated, commodity-exporting economies, and by those with fixed exchange regimes, consistent with the capacity of flexible exchange rates to absorb external

\footnotetext{
${ }^{5}$ The empirical evidence on the linkages between commodity prices and financial sector stability is develping countries is very limited. In a recent work, Kinda et al. (2016) look at a sample of emerging and developing countries and show that negative commodity price shocks are associated with higher non-performing loans and lower bank profitability.
} 
shocks (Edwards and Levy Yeyati, 2005). ${ }^{6}$ In line with what has been established for emerging and advanced economies (Caballero, 2016), we confirm that net capital inflows heighten the propensity of a crisis. However, the inclusion of capital inflows does not increase the predictive power of our model, and there is also no empirical support for the significance of capital inflow surges or bonanzas in our sample. Furthermore, we find that private credit growth, the leading indicator for banking crises in advanced and emerging economies, is not a robust predictor of banking crises and provides no additional predictive power in our sample of low income countries, whether we include this as a continuous variable or via bonanza/surge indicators, suggesting that credit growth in LICs is related to financial deepening rather than boom and bust episodes (Rousseau and Wachtel, 2011). ${ }^{7}$ These results do not imply that domestic factors are unimportant for financial sector stability. On the contrary, low reserve coverage, high inflation and limited trade are all chronic signs of vulnerability or early warning signals of banking crises with substantial economic significance.

Our analysis relates to a large literature that develops a variety of early warning systems for banking crises. The almost dominant view emphasizes the role of credit booms and leverage. Looking at historical data for 14 advanced economies since 1870, Jordà et al. (2011) show that credit growth is the single best predictor of financial instability. In the same vein, a number of influential papers conceptualize how banking crises can break out in the midst of credit booms (Boissay et al., 2016) or provide evidence suggesting that banking crises follow on from credit booms or a sharp increase in leverage (Borio and Drehmann, 2009; Claessens et al., 2011; Gourinchas and Obstfeld, 2012; Schularick and Taylor, 2012; Jordà et al., 2013). More recently, Cesa-Bianchi et al. (2017) go one step further to show that global financial conditions also affect domestic financial stability, since credit growth abroad predicts domestic banking crises above and beyond the effect of domestic credit.

Leverage is not the only significant driver of banking crises. In their historical work spanning the last two centuries, Reinhart and Rogoff (2013, p. 4561) document that "periods of high international capital mobility have repeatedly produced international banking crises" and show that banking crises

\footnotetext{
${ }^{6}$ It is worth stressing the caveat that our analysis is aimed at developing an early warning system for banking crises and, thus, is silent on the complex mechanisms which are behind the association between commodity price fluctuations and banking instability.

${ }^{7}$ In one of the robustness checks we find some evidence for short-term predictive power of private credit growth, but this effect vanishes in our baseline specification when we measure all the explanatory variables as moving averages over three lags.
} 
are more likely when following surges in capital inflows. Consistent with these findings, Caballero (2016) shows that capital inflow bonanzas substantially increase the probability of banking crises and that crises may even be triggered in the absence of excessive lending by domestic banks. More broadly, the early warning literature identifies a variety of factors that are associated with financial crises, which we use as guidance to develop our empirical model. Many studies consistently show that the likelihood of a banking crisis increases after periods of high inflation, with increasing public debt, and after a reduction in real GDP growth and reserves (see, among others, Demirguc-Kunt and Detragiache, 1998; Kaminsky and Reinhart, 1999; Von Hagen and Ho, 2007; Duttagupta and Cashin, 2011; Papi et al., 2015).

We contribute to this literature along two dimensions. First, we emphasize the key role that commodity prices play in triggering financial sector stress. ${ }^{8}$ In a related paper, Agarwal et al. (2017) show that declining commodity prices are associated with worsening bank health and lead to a contraction of bank lending in LICs. Here, we move one step further to assess whether fluctuations in commodity prices can help predict banking crises. Second, while most of the extant literature looks at advanced and emerging markets, we zoom in on the experience of low-income countries. This choice is motivated by the recent rising financial sector vulnerabilities in LICs, by their exposure to fluctuations is commodity prices—as testified by recent macro-financial developments-and by the interest in understanding if the limited number of crises in the last two decades are the result of a commodity super-cycle (see Figure 1). The nagging question lurking in the background is whether the scarcity of banking crises over the past two decades represents the 'new normal,' or whether a prolonged commodity boom coming to an end signals the return to the heydays of LIC crises during the 1980s and early 1990s. To the best of our knowledge, the only work that focuses on (Sub-Saharan African) low-income countries shows that economic slowdown, liquidity shortage in the banking system, and the widening of foreign exchange net open positions help predict crises (Caggiano et al., 2014). With respect to that analysis, we consider commodity prices as a key driver of crisis episodes, and adopt an alternative econometric approach which improves the predictive

\footnotetext{
${ }^{8}$ Most of the macro literature on commodity prices focuses on their effects on output, investment and consumption, while less attention has been paid to the implications for financial sector stability. A few notable exceptions are the work by Caballero et al. (2008) — who look at the interrelations between capital flows to the United States, the commodity boom and the global financial crisis - and Reinhart et al. (2016), whose historical analysis considers the effect of capital flows and commodity price booms on sovereign debt crises.
} 
power of the model on a much larger sample of countries.

The remainder of the paper proceeds as follows: in Section 2 we introduce our sample, discuss variable construction and present results from a number of descriptive exercises including univariate event analysis. Next we briefly discuss our empirical implementation in Section 3 before we present our results, robustness checks and extensions in Section 4. Section 5 concludes.

\section{Data and Descriptive Analysis}

\subsection{Sample}

Our sample is made up of low-income countries presently qualifying for PGRT (Poverty Reduction and Growth Trust) lending under IMF rules. ${ }^{9}$ A total of 73 countries are PRGT-eligible, though 13 of these do not have any or very limited data for our regressions, such that our final sample covers 60 countries, observed over the period 1981-2015. ${ }^{10}$ As Caggiano et al. (2014) point out in their analysis of Sub-Saharan African countries, financial crises in LICs frequently last multiple years. As standard in this literature, our sample excludes observations for 'ongoing' crisis years—for 35 crises in our regression sample this amounts to 70 'ongoing' crisis years (the median crisis event is 2 years long) -in order to avoid the 'post-crisis bias' (Bussière and Fratzscher, 2006), due to the effect that worse macroeconomic conditions during the crisis can have on the estimates (see, for instance, Gourinchas and Obstfeld, 2012; Catão and Milesi-Ferretti, 2014; Papi et al., 2015). ${ }^{11}$ We end up with a sample of 1,550 observations, with an average time series of 25.8 years per country. A list of the countries covered and details about the number of observations and banking crisis events are presented in Appendix Table A-2.

\subsection{Variable Construction and Sources}

We use three main sources for our data on banking crises, commodity price behavior, and macroeconomic, banking and monetary aggregates. First, we adopt the 2017 update of the Laeven and Valencia (2013) database for systemic banking crisis classification, defined by the occurrence of either

\footnotetext{
${ }^{9}$ This sample includes countries currently classified by the World Bank as 'low-income' along with a small number of countries which (very) recently graduated to middle-income status.

${ }^{10} \mathrm{An}$ important caveat is that the sample does not cover the recent swings of commodity prices, which seems to have been associated with rising financial sector vulnerability.

${ }^{11}$ As a robustness check, we include the ongoing crisis years, see Section 4.3.
} 
(i) significant signs of financial distress in the banking system as indicated by bank runs, losses in the banking system, and/or bank liquidations; and/or (ii) significant measures of banking policy intervention in response to substantial losses in the banking system (see Laeven and Valencia, 2013, for further details). During the 1981-2015 sample period, a total of 43 banking crises occurred in our sample, but due to data availability for the control variables our regressions only capture 35 of these; Table A-2 in the Appendix indicates which events we are missing. The distribution of banking crises across years highlights a number of interesting facts (Figure 1): banking crises in poor countries were primarily a feature of the 1980s and 1990s, with only two out of sixty countries (Nigeria and Mongolia) experiencing a banking crisis during the recent Global Financial Crisis (GFC). In contrast, 19 out of 35 high-income countries in the Laeven and Valencia (2013) dataset suffered banking crises as part of the GFC (2007/8), whereas only 12 (half of which were transition economies) experienced crisis events in the 1980 s or 1990 s. $^{12}$ This differential pattern is interesting in light of the widelyacknowledged accelerating pattern of global financial integration over the last two decades, and it further justifies the approach to develop an early warning system specific to low-income countries. It is also notable that 39 of the 43 LIC crises took place during a narrow 15 year-window between 1982 and 1996 - an average of almost three crises per year. As a robustness check we limit our sample to the 1980s and 1990s to carry out crisis prediction in the 'heydays' of LIC financial crises.

Second, we use monthly data for 44 global primary commodity prices from the IMF Primary Commodity Price Database, in combination with annual information on country-specific net export/GDP and export/GDP for each primary commodity collated by Gruss (2014) - the individual commodities are listed in an appendix. Our construction of a country-specific aggregate commodity price (ACP) index differs from that of Gruss (2014) and Bazzi and Blattman (2014) among others, by adopting country-specific commodity weights which are fixed over time:

$$
A C P_{i t}=\sum_{j=1}^{J} \omega_{i j}\left(P_{j t \tau}\right) \text {, }
$$

where $P_{j t}$ is the price of commodity $j$ in month $t$ of year $\tau$ (in US dollars), and $\omega_{i j}$ is the fixed net export/GDP or export/GDP share of commodity $j$ in country $i$. In practice we adopt the mean value

\footnotetext{
${ }^{12}$ Note that the 1970 s saw only a single crisis episode in a low income economy: the Central African Republic in 1977.
} 
over time, $\omega_{i j}^{1}=\sum_{t=1}^{T} \omega_{i j t}$, and in robustness checks the base year value, $\omega_{i j}^{2}=\omega_{i j, 1980}$.

Our choice of fixed commodity weights is based on recent insights from the literature on commodity price shocks and civil conflict, where an earlier result by Bazzi and Blattman (2014) had found no significant impact of price shocks on the outbreak of a civil war. Ciccone (2018), however, argues that the use of time-varying weights conflates the changes in international commodity prices with the changes in type and quantity of commodities exported by a country. Adopting fixed weights, Ciccone (2018) finds a significant impact of commodity price shocks on conflict propensity. His arguments in favour of fixed commodity weights can similarly be applied to our case of financial crises: the conflation of exogeneous price shocks and an endogenous choice of commodity basket and relative volumes substantially undermines the aim to assign a causal effect to commodity price shocks in their impact on financial crises, since (i) the type and volume of a country's commodity exports may change due to observable economic, political or social changes which also affect crisis propensity directly, ${ }^{13}$ and (ii) a country's export basket may change due to unobservable factors which also affect crisis propensity. Ciccone (2018) further shows that the use of weights averaged over the sample period (in our case: 1981-2015) has the advantage of mitigating attenuation bias arising from the mismeasurement of export shares.

Since we rely on average net export/GDP weights in our main results-qualitatively identical results adopting base year weights are confined to an appendix-we define primary commodity price shocks as simply the first difference of our aggregate commmodity price measure, $\triangle A C P_{i t}=A C P_{i t}-A C P_{i, t-1}$, rather than the first difference of the price in logs. These monthly shocks are then summed over the calendar year to obtain annual values. Below we refer to this variable as 'commodity price growth.' In addition we adopt a measure of aggregate commodity price volatility by computing the $12-$ month rolling standard deviation of $\triangle A C P_{i t}$. The volatility measure for January is taken as the indicator for the previous calendar year, and below we refer to this variable as 'commodity price growth volatility' or simply 'price volatility.' ${ }^{14}$

Third, informed by the existing literature on banking crises—see the seminal contributions by

\footnotetext{
${ }^{13}$ For instance a desire to earn foreign currency for cash crops can be directly linked to the accumulation of foreign reserves.

${ }^{14}$ We also experimented with a more differentiated measure of price volatility following Danielsson et al. (2016), emphasising positive versus negative deviations from the HP-filtered price trend, but these did not yield any statistically significant differences and are therefore not reported here.
} 
Demirguc-Kunt and Detragiache (1998) and Kaminsky and Reinhart (1999), and the recent review by Kauko (2014)—we collate a set of control variables (in the main specification or robustness checks) organized into rubrics of: (i) macroeconomic fundamentals (real GDP growth, inflation, currency depreciation, public debt/GDP); (ii) external sector variables (net capital inflows/GDP, also disaggregated into FDI and non-FDI flows, aid/GNI, trade openness); (iii) monetary indicators (growth of domestic (private) credit/GDP, M2/reserves); (iv) measures of banking system structure (liquidity, size); (v) a measure of global economic activity (the 10-year US Treasury Constant Maturity Rate); and (vi) indicator variables for armed conflict, deposit guarantee schemes, fiscal crises, and currency crises. ${ }^{15}$ All these variables are retrieved from standard sources, including the World Bank World Development Indicators, the IMF International Finance Statistics and World Economic Outlook. Further details on the definitions and sources for each variable are provided in Appendix A. All variables are expressed as growth rates or ratios, which are less likely to be characterized by a stochastic trend, and are winsorized at the top and bottom $2.5 \%$ of observations. Descriptive statistics for the full sample are presented in Appendix Table A-1.

\subsection{Variable Transformation}

One important aspect of the empirical modelling of financial crises is how to account for the precrisis dynamics of macroeconomic variables in the construction of an early warning approach to crisis prediction. In this context, the standard practice in the papers reviewed in Papi et al. (2015, Table 2), Kauko (2014) and Klomp (2010) is to lag the regressors, typically by just a single time period. This choice seems somewhat ad hoc and may fail to adequately capture the prevailing dynamics in the run-up of a crisis. In fact, Eichengreen (2003, p. 157) argues that "[b]anking crises [...] are rooted in slowly evolving fundamentals like falling economic growth and adverse external shocks", and Schularick and Taylor (2012) employ lag polynomials of length five in their seminal analysis of advanced economies over the 1870-2010 period. Given the comparatively short time series dimension of our data (less that 35 years as opposed to 140 years in Schularick and Taylor, 2012) along with

\footnotetext{
${ }^{15}$ Given the literature on the costs of twin crises (Kaminsky and Reinhart, 1999; Hutchison and Noy, 2005), one may be worried by the overlap and interconnections between currency, fiscal and banking crises. In particular, the concern is that a banking crisis may be the consequence of a currency or fiscal crisis. This occurrence is very infrequent in our sample, where the crisis episodes that follow a currency or a fiscal crisis number 6 and 2, respectively (Figures B-3 and B-4 in the Appendix). Nonetheless, we explicitly account for these episodes adding the dummies for past currency and fiscal crises.
} 
the large number of candidate crisis determinants included in the model, we favor the adoption of moving averages to capture pre-crisis dynamics, as practiced by Reinhart and Rogoff (2011) and Jordà et al. (2011, 2016). Based on the below event analysis we select an MA(3) process (capturing values at $t-1, t-2$, and $t-3)$ for our main set of results, though we also present findings for a single lag and MA-transformations for 2, 4, or 5 lags.

A related question refers not to the pre-crisis dynamics of crisis predictors but the crisis dynamics themselves: whenever we encounter repeated events, it may be of importance to establish whether having had a crisis (recently) is an important determinant in the prediction of a crisis. If this is the case, one approach would consist of employing a dynamic specification. However, specifying a dynamic model raises significant difficulties for estimation and interpretation in non-linear models with country fixed effects. We argue that in our context this is not necessary for two reasons. First, only seven out of the 29 sample countries which experienced at least one crisis experienced multiple crises, but the maximum crisis number here is still just two: like in advanced and emerging countries, banking crises in LICs are still relatively rare events. ${ }^{16}$ Second, recent work by Bouvatier (2017, p. 20) investigating the time-dependence effect in the occurrence of banking crises finds that when focusing on relatively short time horizons such as the three to four decades typically employed in EWS analysis, "the time-dependence effect vanishes with the inclusion of a full set of standard determinants of banking crises."

\subsection{Event Analysis}

As an initial descriptive tool we follow the practice in, inter alia, Gourinchas and Obstfeld (2012) and Anundsen et al. (2016) and conduct an event analysis-a univariate test of variable behavior in the vicinity of the banking crisis event. ${ }^{17}$ We estimate the following fixed effects model separately for each variable $k$ :

$$
y_{i t}^{k}=\alpha_{i}^{k}+\beta_{s}^{k} \delta_{i s}+\varepsilon_{i t}^{k},
$$

\footnotetext{
${ }^{16}$ We also employed a rare events logit implementation following King and Zeng (2001) for robustness - results were qualitatively identical to the standard logit results reported in column 5 of Table 1.

${ }^{17}$ Note that Gourinchas and Obstfeld (2012) study multiple forms of financial crises in a single equation, as their empirical setup is aimed at studying the global financial crisis against the background of previous crises. Since in our sample only two economies experienced crises in 2007-2008 we do not single out the GFC in our analysis.
} 
where $\delta_{i s}$ is a dummy variable equal to one when country $i$ is $s$ years away from the crisis, $t$ indexes the years between 1981 and 2015, $\alpha$ is the country fixed effect and $\varepsilon$ is a white noise error term. We let $s$ vary from -5 to +5 , such that we evaluate each variable in the lead-up and aftermath of a banking crisis relative to the observations outside this 11-year window, with the latter interpreted as 'tranquil' times. We estimate this equation using robust standard errors to weigh down the impact of influential outliers.

Figure 3 presents results for a number of key variables. ${ }^{18}$ The whiskers in these plots represent $90 \%$ confidence intervals, which are fairly wide in the case of most variables, as is not uncommon in this kind of exercise (see, for instance, Gourinchas and Obstfeld, 2012).

Starting from our key variables of interest, we see that commodity price growth follows a cyclical behavior, with a large and significant drop in the lead-up to crises and a recovery starting soon after. The commodity price volatility measure is consistently above the value in tranquil periods, suggesting that one should focus not only on the growth, but also on the volatility of aggregate commodity prices. The growth rate of credit to the private sector as a share of GDP does not show any upward trend in the lead-up to the crisis. Our evidence shows that, if anything, private credit is depressed prior to crisis events, and it picks up only three years after the banking crisis. This pattern is different from what is observed in advanced economies where credit booms and busts have been identified as one of the key drivers of banking crises (Kaminsky and Reinhart, 1999; Jordà et al., 2011, 2015; Schularick and Taylor, 2012), and it further justifies the choice to focus our analysis exclusively on a sample of low-income countries.

Moving to macroeconomic fundamentals, the stylized facts seem to be more in line with what is observed for countries in other income groups. Prior to crisis events GDP growth is about one percentage point lower than in tranquil times, but seems to recover fairly quickly thereafter. On the fiscal side, the public debt-to-GDP ratio starts increasing two years ahead of the crisis to levels that are almost 10 percent higher than in normal times, and then it further increases to levels almost 20 percent higher, confirming that banking crises have long-lasting effects on public debt levels (Reinhart and Rogoff, 2013).

\footnotetext{
${ }^{18}$ One potential caveat in this type of descriptive analysis is the overlap of event windows when countries experience multiple crises. In a robustness check we dropped all countries in the sample with two crises and found qualitatively identical results (available on request).
} 
The analysis of monetary variables confirms that the extent to which the liabilities of the banking system are backed by international reserves is a leading indicator of banking crises (Kaminsky and Reinhart, 1999). Broad money relative to foreign exchange reserves is significantly higher ahead of the crisis compared to tranquil times, even if it starts declining well ahead of the crisis event. Inflation is on average about 2 to 3 percent above 'tranquil' times and then goes down to non-crisis values three years after the event. Net non-official capital inflows as a share of GDP show only minimal movements related to banking crisis events, with a significant decline, but only somewhat larger than one percent of GDP, in the crisis year. This result is in stark contrast to developments in advanced countries and emerging markets, where capital inflow bonanzas play a significant role in predicting banking crises (Reinhart and Rogoff, 2013; Caballero, 2016). To some extent, this pattern could be explained by the relative low levels of non-official capital inflows during the 1980s and 1990s when most of the banking crises in low-income countries happened. By contrast, foreign aid inflows as a share of GDP are significantly higher in the lead-up to the crisis than in normal times, and further increase after the event, providing further evidence in support of the presence of large and persistent costs of banking crises.

The evolution of trade openness indicates a small drop prior to the event, but their low level points to the substantial increase in trade since the turbulent 1980s and 1990s when virtually all crises occurred. ${ }^{19}$ Finally, when looking at the characteristics of the domestic banking system, we observe that total bank assets are smaller than in normal time, even before the crisis, re-enforcing the argument that expansionary credit growth does not seem to be a key leading indicator for banking crises in LICs. Bank liquidity, instead, significantly increases before the crisis event, suggesting that financial crises could have an origin in the real sector, reflected in lower commodity prices and output growth, fiscal strains_-as shown by rising public debts—and banks more inclined to buy liquid government bonds rather than lending to household and corporates.

Overall, this simple univariate analysis provides some interesting insights. While some of the 'traditional' crisis predictors found to matter greatly in the advanced economy context—such as credit growth and capital inflows-show less clear patterns in low-income countries, real-sector variables and especially commodity terms of trade emerge as key indicators to monitor. However, the evidence

\footnotetext{
${ }^{19}$ The 'tranquil' times are thus the more recent period with higher levels of globalisation and trade, hence the levels shift for openess. A similar argument applies for size and (in reverse) foreign aid.
} 
presented here is at best indicative, and we now turn to the discussion of the more formal regression analysis in our study.

\section{Empirical Model and Implementation}

We follow the vast majority of studies in the financial crises literature and estimate a latent crisis model, where the observed variable (the crisis event) is a realized systemic crisis when the latent variable exceeds some threshold. We code the crisis variable as equal to one in the year the banking crisis started, and zero otherwise, and we exclude 'ongoing crisis' years from the sample, as discussed above. All our explanatory variables are transformed into three-year moving averages, $M A(3)$, with results for alternative lag structures also presented.

A key issue to confront in order to obtain meaningful estimates of the effect of explanatory variables on the likelihood of banking crises is unobserved cross-country heterogeneity. We adopt two empirical implementations to deal with this issue by allowing for country-specific fixed effects, which give all coefficients the interpretation of 'within' country estimates and bring us closer to a plausibly causal interpretation of the results, but at the same time are not subject to the incidental parameter problem. ${ }^{20}$ Fernandez-Val and Weidner (2016) propose a logit fixed effects estimator which removes an analytical estimate of the incidental parameter bias from a standard logit model with fixed effects. One disadvantage of this implementation, along with any existing versions in this literature where fixed effects are simply included in a pooled logit model (e.g. Anundsen et al., 2016; Cesa-Bianchi et al., 2017) is that the regression sample is limited to those countries which experienced a crisis at one point during the sample period-in our case this amounts to only 29 economies. Our above arguments in favour of retaining countries with no history of banking crises aside, one might note that 'crisis event' dating is by no means an exact 'science' and clearly subject to debate (Laeven and Valencia, 2013), making it advantageous to triangulate results with a method which allows all countries with available data-in our case 60 economies - to be included in the regressions.

To overcome this limitation, we follow Caballero (2016), who provides a useful illustration of

\footnotetext{
${ }^{20}$ The problem arises from the limited number of observations available to estimate the country-fixed effects, which are 'nuisance' parameters in the sense that we are typically not interested in the fixed effects themselves but what they do to the slope coefficients on the variable(s) of interest. When $N$ rises (asymptotically) and $T$ is fixed, the number of these nuisance parameters to be estimated grows as quickly as $N$, which gives rise to the asymptotic bias (Neyman and Scott, 1948).
} 
a well-established empirical approach to get around the incidental parameter problem in nonlinear models, which goes back to Mundlak (1978) and a generalisation by Chamberlain (1982). The implementation (henceforth RE-Mundlak Logit) builds on a random effects logit model, where the strong assumption of no correlation between the individual (in our case country-specific) effects and the covariates can be relaxed by separately including estimates of the country-specific means of each covariate. ${ }^{21}$ This approach has the additional advantage that countries which never experienced a crisis are not excluded from the sample, and that the statistical significance of accounting for country-specific effects can easily be tested. ${ }^{22}$ As a result, we adopt the RE-Mundlak logit as our preferred empirical implementation, but also present findings for standard pooled logit and fixed effects logit implementations. ${ }^{23}$ Standard errors in all logit regressions are clustered at the country level. We typically present a version of average marginal effects where we multiply the margins with the standard deviation of the covariate to create magnitudes comparable across variables and specifications (expressed in \%); the computation of the standard errors for these margins in turn is based on the Delta method.

Finally, we are interested in showing that augmenting a standard model for banking crises with aggregate commodity price movements does actually improve the predictive power of the empirical model. To this purpose, we use the Receiver Operating Characteristic (ROC) curve along with the associated AUROC (area under the ROC curve) statistic, which has become a prominent feature of the empirical literature on financial crises (see Jordà et al., 2011; Schularick and Taylor, 2012; Anundsen et al., 2016, for detailed discussion). A higher AUROC statistic indicates better predictive power (a value of 0.5 is the benchmark for any informative model, where predictive power of the model is equivalent to the flip of a coin), and that statistical tests to compare the predictive power of different models can be constructed given the availability of AUROC standard errors. When plotting the ROC curves, the further to the North-West the curve, the better the predictive power of the

\footnotetext{
${ }^{21}$ See Caballero (2016) for a more formal discussion. A second popular application of this approach is when observed characterstics are time-invariant, which would be dropped due to perfect collinearity in a standard fixed effect model. In an RE-Mundlak model time-series means can be included for those covariates which are time-variant, with the resulting estimates subject to a 'fixed effects' interpretation, while the time-invariant observables are included without these time-series means.

${ }^{22}$ Comparing conditional and unconditional probabilities of crises can also overcome the sample selection issue, but the magnitudes of the estimated effects in a univariate setting are likely to be biased.

${ }^{23}$ For the latter we adopt the bootstrap to compute standard errors. Given the limited numbers of crisis events, we also estimate our model using a rare event logit estimator (King and Zeng, 2001), finding results very similar to those obtained with a standard logit.
} 
model; and if ROC curves cross, then the statistical comparison of two AUROC statistics can indicate whether one model still performs better in a statistical sense.

\section{Results and Discussion}

\subsection{Main results}

Our main results are presented in Table 1, focusing on selected variables of interest, with the full results available in Appendix Table B-1-with the exception of the analysis of bonanzas and surges in Tables 5 and 6 all coefficients reported in this and the below tables are marginal effects, constructed as the percentage marginal effect of a one standard deviation increase in the variable. In the first specification in Table 1 we focus on commodity price growth and volatility, controlling only for US interest rates and for the presence of deposit insurance and fiscal and currency crises. In columns 2 to 4 we then saturate the model with sets of bank, macro and external sector controls.

These estimates point to three main findings. First, we find a negative and robust association between commodity price growth and the likelihood of a banking crisis. The point estimate remains substantial in magnitude and precisely estimated even when we saturate the model with additional covariates, which contribute to the overall goodness of fit of the model. In economic terms, the estimated coefficient in column 4 implies that a 1 SD decline in the annual growth of aggregate commodity prices is associated with a 1.4 percentage point higher probability of a banking crisisa relatively large effect given that the unconditional in-sample propensity of banking crises is 2.3 percent. By contrast, the positive coefficient on the volatility of commodity price growth is not robust, since adding macroeconomic controls washes out the significance of the coefficient.

Second, consistent with the evidence shown in the event study, we find that there is no indication that credit growth matters for the occurrence of banking crises. This claim, albeit surprising in light of the evidence on advanced and emerging economies, is supported by additional evidence, which we discuss in Section 4.4. Similarly, none of the banking system variables (column 3)-liquidity and size (reported in Appendix Table B-1) — show a robust correlation with the crisis dummy.

Third, adding external sector variables indicates that banking crises are more likely after periods of high net private capital inflows, high foreign aid inflows and low trade, whose effects on the 
occurrence of banking crises are economically sizable. In particular, the effect of capital inflows is similar in magnitude to that of commodity prices growth, as 1 SD increase in the ratio of net capital inflows over GDP is associated with a 1 percentage point increase in the likelihood of a crisis. Note that the vulnerability brought about by commodity price shocks is further increased when we control for other external sector variables.

With regards to other control variables, we see that crisis episodes are more likely to follow periods when the growth of banking system liabilities is not backed by international reserves, or following periods of higher inflation, while there is no robust evidence that public debt or real GDP growth are significant predictors of crisis events. ${ }^{24}$ While most of the unreported coefficients are not statistically significant, there is evidence that crises are more likely in periods of tight global monetary conditions, see Table B-1 in the Appendix.

\subsection{Goodness of Fit}

The inclusion of macroeconomic and external sector variables increases the predictive power of the model (i.e. the AUROC is statistically greater than in the reduced model with only banking system variables). While in the fully-augmented model (column 4) the coefficients on the aggregate commodity price growth is still precisely estimated, a key concern in this kind of exercise is that the additional variables are not only significant, but actually increase the predictive power of the model. Thus, we compare the model in column 4 with the same specification without the commodity price variables. The resulting ROC curves are plotted in Figure 4 (panel a), which shows that the inclusion of aggregate commodity price growth significantly increases the predictive power of the model, as the AUROC increases from 0.851 to 0.882 and the difference between the two values in statistically different from zero.

The comparison between our preferred specification (column 4), the standard pooled logit model (column 5), as well as the bias-corrected logit FE (column 6) shows that the predictive power of the RE-Mundlak logit model is substantially and statistically significantly higher than that of the two alternatives, as illustrated by the ROC curves plotted in Figure 4 (panel b) and AUROC

\footnotetext{
${ }^{24}$ We have experimented with different non-lienar specification through which debt could affect the likelihood of banking crises, even isolating the Heavily Indebted Poor Countries, but without robust evidence that debt is a predictor of future banking crises.
} 
comparison tests reported. While our key result on the importance of commodity price growth is confirmed in the pooled logit, the estimates based on the FE model are much less stable and less precisely estimated to the point that almost all covariates lose their statistical significance, signaling that the reduction in the sample size, due to that fact all countries without banking crises are excluded from the sample, is a serious constraint. By contrast, the standard logit model preserves the same sample, but provides point estimates that are also often quite different from those of the RE-Mundlak logit model, suggesting that simply pooling the data-and avoiding a within-country interpretation of the results_-provides quite a different, arguably misleading, picture.

\subsection{Robustness of the Baseline}

Table 2 provides robustness checks using various restricted samples and data transformation. The first column reports our preferred specification (column 4 of Table 1), while columns (2) to (4) replicate this model with different sub-samples. We start in column (2) by dropping countries with less than 15 observations, to have a more balanced panel, then we retain the 'on-going crisis' observations in column (3). In column (4) we restrict the sample to the period 1981-2000, when most crises took place. Results are generally consistent across samples and the coefficient on our key indicator related to commodity price growth remains statistically significant and stable across the different samples. Only in the last of these exercises the magnitude increases, but this is easily explained by the fact that the in-sample probability of crisis is also significantly higher.

Recent work by Cesa-Bianchi et al. (2017) emphasizes the need to account for global financial conditions in the analysis of domestic banking crises, and implements this challenge by introducing GDP-weighted averages of credit growth abroad in a specification which speaks to the parsimonious analysis in Schularick and Taylor (2012). ${ }^{25}$ They conclude that credit booms elsewhere in the world have a large economic effect on the propensity of a crisis and that their inclusion significantly increases the predictive power of the model. Although the weighting scheme may account for some small deviations, their empirical strategy can actually capture unobserved common shocks to the global economy, but assumes the impact of these shocks is described adequately by the GDP-weights

\footnotetext{
${ }^{25} \mathrm{An}$ earlier variant to account for global activities in the context of currency crises is to include a dummy for 'crisis elsewhere' in the analysis of quarterly data for advanced economies in Eichengreen et al. (1996)-given the distribution of crises (see Figure 1) this would in practice amount to a dummy for the 1980s and 1990s and is unlikely to affect estimates on other covariates.
} 
(see also recent work by Boneva and Linton, 2017, this is a variant of the common practice in the linear panel time series literature to take variables in deviation from the cross-section mean, CS-DM).

In column (5) of Table 2 we express all variables as deviations from the cross-country average and then estimate our model with the RE-Mundlak Logit. We prefer this implementation since the large number of covariates in our model makes the inclusion of (weighted) 'global' averages unfeasible in our present setup. As suggested, similar to the inclusion of year fixed effects, this transformation can take into account the role of unobserved time-varying global shocks. Even in this much more demanding specification, the coefficient on aggregate commodity price growth is precisely estimated and close in magnitude to that of the baseline. The same is true for net capital inflows and for reserves, while taking into account global shocks implies that foreign aid inflows and trade openness are no longer significant predictors of banking crises.

Next, we test the robustness of our results to the inclusion of a wide battery of other potential drivers of financial instability (see Table B-2 in the Appendix for results). We start by further addressing the possibility that global financial conditions matter and we include a measure of global credit (column 2), one of global capital flows (column 3), and one of global debt (column 4). Following the practice in Cesa-Bianchi et al. (2017) these variables are constructed for each country $i$ as the cross-section averages of credit, capital flows and debt for all other countries at time $t$ (i.e. excluding country $i$ ). Then, from column 6 onward we control for a large set of macroeconomic variables: exchange rate depreciation, a measure of concentration of aid inflows-which is a proxy of vulnerability to foreign donor financing, - the ratio of debt service over exports, the share of shortterm debt over total external debt, and the presence of conflicts. None of them turn out to be significant predictors of banking crises, while at the same time the coefficient on commodity price growth remains stable and precisely estimated.

We then assess the robustness of our results to changes in the lag structure of the explanatory variables in Table 3. We start by using a single lag, and then take moving average transformation for all covariates going from $T=2$ to $T=5$. Note that selecting a single lag risks conflating the predictor variable with the anticipation of the imminent banking crisis event, while a much longer lag specification may wash out short-lived but important spikes in the lead-up to the crisis. The main takeaway from this exercise is that our results are remarkably robust to alternative dynamic 
transformation of the data. The coefficient on commodity price growth is negative and precisely estimated in all models, with the only exception of the $M A(2)$ transformation, where, however, the $t$-statistics is close to the 10 percent confidence level. The other results are also confirmed across alternative lag structures of the covariates and, interestingly, we find some evidence that faster credit growth is indeed associated with a higher likelihood of a crisis event, at least if we limit the window to up to two years. This result would suggest that credit growth could indeed have some predictive power in the unfolding of the crisis. In contrast, real GDP growth and public debt are never good predictors of banking crises.

Finally, we want to reiterate the significance of choosing fixed weights for the construction of the aggregate commodity price variables (Ciccone, 2018). In Appendix Tables B-3 and B-4 we first show that our results are qualitatively identical if we use base year net exports/GDP as weights and yield marginally smaller aggregate commodity price growth margins if we adopt mean exports/GDP as weights instead. In Table B-5 we demonstrate that this substantial impact of commodity price movements is significantly attenuated if we adopt annual net exports/GDP weights instead of the fixed weights; note that the margins for the other covariates are seemingly unaffected by this change.

\subsection{The Role of Leverage}

Our main results show that aggregate commodity price movements are a key driver of banking crises in low-income countries. We also find that capital inflows are associated with a higher likelihood of crisis, while the evidence for leverage is much less convincing, in contrast to an extensive literature indicating excessive credit growth as the key leading indicator of financial crises. In light of the importance of credit booms for financial stability —at least in advanced economies and emerging markets (Jordà et al., 2011; Gourinchas and Obstfeld, 2012; Reinhart and Rogoff, 2013)—our focus in this section is on the role of leverage and we explicitly model bonanzas and surges in private credit, following the definitions proposed by Caballero (2016) for bonanzas and by Ghosh et al. (2014) for surges. ${ }^{26}$

\footnotetext{
${ }^{26}$ Bonanzas are defined as large deviations from the HP-filtered trend of private credit and net capital inflows (both expressed in percent of GDP), where one variant adopts a one standard deviation-threshold and another a two standard deviation one (see Caballero, 2016, for details). Surges are defined as exceptional levels of net capital inflows or real private credit (again expressed in percent of GDP)—specifically, levels that are in the top 30th percentile of both the country-specific and the full sample distribution (following Ghosh et al., 2014). Note that the surges are computed for the full set of available data in each country, not the regression sample. Again we have two variants: one is the
} 
We start by looking at credit growth. Table 4 replicates our main findings but begins from a simple model specification including only credit growth and then incrementally saturates the model with control variables. In the first two columns the coefficient on credit growth is negative (thus the opposite sign to that expected from the literature, albeit in line with our event analysis above) and in one case significant (column 2), ${ }^{27}$ but it then turns positive and statistically insignificant once standard controls are included in the model. Thus, even in more parsimonious models like that in column 3, we do not find evidence that leverage leads to financial instability in LICs.

Next, we look at a possible non-linear effect of credit considering bonanzas and surges in Table 5-note that for ease of interpretation of these nonlinearities alongside continuous commodity price variables we report the raw logit results here, with our discussion thus focused on sign and statistical significance. The coefficient on commodity price growth again remains remarkably stable, while we do not find any indication of boom and bust episodes, consistent with what is shown in the event study analysis. Moreover, consistent with the hypothesis that LICs are mostly undergoing a process of financial deepening, we observe that while the number of surges is relatively large, the number of bonanzas is extremely small: 11 episodes ( 0.7 percent of country-year observations in the sample) when considering the one standard deviation threshold, and only one bonanza (Nigeria in 2009) with the two standard deviation threshold — the latter specification cannot identify the bonanza coefficient and we therefore omit the results for this specification.

\subsection{Capital Inflows Bonanza}

In Table 6 we replicate the bonanza and surge analysis considering net private capital inflows (top panel), and then separating these into FDI and non-FDI inflows (bottom panel)-again we report raw RE-Mundlak logit coefficients. Contrary to the findings in Caballero (2016) for a large sample of advanced and emerging economies, while we observe that banking crises are more likely after a period of higher net capital inflows (column 1), our results do not point to significant non-linearities. Capital inflows bonanzas and surges do not increase the likelihood of banking crises in LICs, regardless of the way in which these episodes are defined. In addition, splitting capital inflows into their FDI

simple surge indicator just described for time $t$, another (labelled 'consec' for 'consecutive surges' below) only identifies a surge if the first variant indicator is equal to one at time $t-1, t$, and $t+1$.

${ }^{27}$ Note that we are unable to compute standard errors for the margins in column 1 , possibly due to the parsimonious nature of the model. 
and non-FDI components, on the grounds that the latter may be more volatile and more likely to propagate into financial sector instability, does not add further insights. If anything, the coefficient on non-FDI capital blow bonanza is negative (and significant) when they are defined using the one standard deviation-threshold, but this result does not hold when considering a stricter definition of bonanzas or when looking at non-FDI surges. Importantly, the negative coefficient on commodity price growth remains stable and precisely estimated across all specifications.

\subsection{Cross-Sectional Heterogeneity}

As a final exercise we exploit the cross-sectional dimension of our sample to test whether commodity price growth is a leading indicator of banking crises for all low-income countries or, alternatively, its effect is limited to some specific set of countries ('regimes'—see table footnote for details on how we determine country membership in the base or regime category). Export orientation and the composition of the export basket, as well as the exchange rate regime are natural candidates for analysis. $^{28}$

We first consider the exchange rate regime using the recent classification proposed by Ilzetzki et al. (2017) to separate flexible from fixed regimes, the latter including both hard and crawling pegs. Consistent with the evidence of flexible exchange rates as shock absorbers (Edwards and Levy Yeyati, 2005), we find that commodity price growth only matters for the likelihood of banking crises in countries with fixed exchange rates (the 'regime' results are statistically significant), while the other countries ('base') may be able to use exchange rate flexibility to at least partially offset the external shock coming from commodity prices (Table 7 , column 2).

Next we split our sample in two based on countries' export/GDP level; results presented in column 3 use country averages to determine the split, though if we use annual data we obtain qualitatively identical results. We find that countries with relatively high export/GDP ratio are significantly affected by commodity price swings, whereas the effect is insignificant for those with low export ratios.

Finally, we split our sample between diversified and commodity exporters and allow the coefficient on the aggregate commodity price growth two differ between the two groups. Results—shown

\footnotetext{
${ }^{28} \mathrm{We}$ have also tested for the presence of asymmetries. Results qualitatively suggest that fall in commodity prices are what really matters for financial stability.
} 
in column 5 of Table 7-indicate that a fall in commodity prices is associated with the occurrence of a banking crisis in commodity exporters, and the effect is about 50 percent larger than that estimated over the whole sample (see benchmark for marginally smaller sample in column 4). By contrast, commodity prices are not a source of financial instability in diversified exporters.

\section{Concluding Remarks}

Leverage - and to some extent capital inflows - are often highlighted as the key drivers of financial instability and crises. This conclusion is based on an extensive literature on advanced economies and emerging markets. We suggest that the same arguments cannot be transferred one-for-one to the developing country context, given these countries' different economic and financial structure. Hence, we estimate a model to predict banking crises in low-income countries and show that: (1) commodity price movements are a key driver of crisis episodes; (2) net private capital inflows also play a role, consistent with the increasing financial integration in several LICs; and (3) credit to the private sector does not display robust predictive power, suggesting that credit developments in LICs have more to do with financial deepening than with boom and bust episodes.

There is broad evidence that low-income countries are vulnerable to commodity price movements, which can explain a large share of output fluctuations. Our analysis shows that a channel through which commodity price movements can affect the real economy is via their effect on financial stability. This is especially true for commodity exporters and more integrated economies with fixed exchange rate regimes. Overall, our analysis indicates that commodity prices are a key element to design an early warning system for LICs, as their inclusion significantly increases the predictive power of the model. In light of this evidence, recent swings in commodity prices should be carefully monitored also because of their potential effects on financial sector stability.

\section{References}

Agarwal, I., Duttagupta, R., and Presbitero, A. F. (2017). Commodity prices and bank lending in low-income countries. International Monetary Fund, Working Paper WP/17/279. 
Aizenman, J. and Noy, I. (2013). Macroeconomic adjustment and the history of crises in open economies. Journal of International Money and Finance, 38:41-58.

Anundsen, A. K., Gerdrup, K., Hansen, F., and Kragh-Sørensen, K. (2016). Bubbles and Crises: The Role of House Prices and Credit. Journal of Applied Econometrics, 31(7):1291-1311.

Araujo, J., David, A. C., van Hombeeck, C., and Papageorgiou, C. (2017). Non-FDI Capital Inflows in Low-Income Developing Countries: Catching the Wave? IMF Economic Review, 65(2):426-465.

Bazzi, S. and Blattman, C. (2014). Economic shocks and conflict: Evidence from commodity prices. American Economic Journal: Macroeconomics, 6(4):1-38.

Beck, T., Demirguc-Kunt, A., and Levine, R. (2006). Bank concentration, competition, and crises: First results. Journal of Banking \& Finance, 30(5):1581-1603.

Bleaney, M. and Greenaway, D. (2001). The impact of terms of trade and real exchange rate volatility on investment and growth in sub-Saharan Africa. Journal of Development Economics, 65(2):491-500.

Bluedorn, J. C., Duttagupta, R., Guajardo, J., and Mwase, N. (2014). What underlies the recent growth comeback in developing economies? Journal of Policy Modeling, 36(4):717-744.

Boissay, F., Collard, F., and Smets, F. (2016). Booms and Banking Crises. Journal of Political Economy, 124(2):489-538.

Boneva, L. and Linton, O. (2017). A discrete-choice model for large heterogeneous panels with interactive fixed effects with an application to the determinants of corporate bond issuance. Journal of Applied Econometrics, 32(7):1226-1243.

Bordo, M. D. and Meissner, C. M. (2016). Fiscal and financial crises. In Handbook of Macroeconomics, volume 2, pages 355-412. Elsevier.

Borio, C. and Drehmann, M. (2009). Assessing the risk of banking crises - revisited. BIS Quarterly Review, pages 29-46.

Bouvatier, V. (2017). The frequency of banking crises in a dynamic setting: a discrete-time duration approach. Oxford Economic Papers, 69(4):1078-1100. 
Bussière, M. and Fratzscher, M. (2006). Towards a new early warning system of financial crises. Journal of International Money and Finance, 25(6):953-973.

Caballero, J. A. (2016). Do Surges in International Capital Inflows Influence the Likelihood of Banking Crises? Economic Journal, 126:281-316.

Caballero, R. J., Farhi, E., and Gourinchas, P.-O. (2008). Financial Crash, Commodity Prices, and Global Imbalances. Brookings Papers on Economic Activity, 2008(Fall):1-55.

Caggiano, G., Calice, P., and Leonida, L. (2014). Early warning systems and systemic banking crises in low income countries: A multinomial logit approach. Journal of Banking \& Finance, 47:258-269.

Catão, L. and Milesi-Ferretti, G. M. (2014). External liabilities and crises. Journal of International Economics, 94:18-32.

Cesa-Bianchi, A., Martin, F. E., and Thwaites, g. (2017). Foreign Booms, Domestic Busts: The Global Dimension of Banking Crises. Bank of England working papers 44, Bank of England, London.

Chamberlain, G. (1982). Multivariate regression models for panel data. Journal of Econometrics, 18(1):5-46.

Ciccone, A. (2018). International commodity prices and civil war outbreak: new evidence for SubSaharan Africa and beyond. CEPR Discussion Paper 12625.

Claessens, S., Kose, M. A., and Terrones, M. E. (2011). Financial Cycles: What? How? When? NBER International Seminar on Macroeconomics, 7(1):303-344.

Danielsson, J., Valenzuela, M., and Zer, I. (2016). Learning from history: volatility and financial crises. SRC Discussion Paper 57, London School of Economics and Political Science.

Deaton, A. (1999). Commodity prices and growth in africa. Journal of Economic Perspectives, 13(3):23-40.

Demirguc-Kunt, A. and Detragiache, E. (1998). The determinants of banking crises in developing and developed countries. IMF Staff Papers, 45(1):81-109. 
Demirguc-Kunt, A., Kane, E. J., and Laeven, L. (2008). Determinants of deposit-insurance adoption and design. Journal of Financial Intermediation, 17(3):407-438.

Duttagupta, R. and Cashin, P. (2011). Anatomy of banking crises in developing and emerging market countries. Journal of International Money and Finance, 30(2):354-376.

Edwards, S. and Levy Yeyati, E. (2005). Flexible exchange rates as shock absorbers. European Economic Review, 49(8):2079-2105.

Eichengreen, B., Rose, A. K., and Wyplosz, C. (1996). Contagious currency crises: first tests. Scandinavian Journal of Economics, 98(4):463-484.

Eichengreen, B. J. (2003). Predicting and Preventing Financial Crises: Where Do We Stand? What Have We Learned. In Siebert, H., editor, Global governance : an architecture for the world economy. Springer.

Fernández, A., Schmitt-Grohé, S., and Uribe, M. (2017). World Shocks, World Prices, And Business Cycles: An Empirical Investigation. Journal of International Economics, 108:S2-S14.

Fernandez-Val, I. and Weidner, M. (2016). Individual and time effects in nonlinear panel models with large N, T. Journal of Econometrics, 192(1):291-312.

Gerling, K., Medas, P. A., Poghosyan, T., Farah-Yacoub, J., and Xu, Y. (2017). Fiscal crises. International Monetary Fund, Working Paper WP/17/86.

Ghosh, A. R., Qureshi, M. S., Kim, J. I., and Zalduendo, J. (2014). Surges. Journal of International Economics, 92(2):266-285.

Gourinchas, P.-O. and Obstfeld, M. (2012). Stories of the twentieth century for the twenty-first. American Economic Journal: Macroeconomics, 4(1):226-265.

Gruss, B. (2014). After the boom-commodity prices and economic growth in Latin America and the Caribbean. IMF Working Paper 14/154, International Monetary Fund, Washington DC.

Hutchison, M. M. and Noy, I. (2005). How bad are twins? Output costs of currency and banking crises. Journal of Money, Credit, and Banking, 37(4):725-752. 
Ilzetzki, E., Reinhart, C. M., and Rogoff, K. S. (2017). Exchange Arrangements Entering the 21st Century: Which Anchor Will Hold? NBER Working Paper 23134, National Bureau of Economic Research.

International Monetary Fund (2015). World Economic Outlook - Adjusting to Lower Commodity Prices. International Monetary Fund, Washington DC.

International Monetary Fund (2017). Macroeconomic Development and Prospects in Low-Income Developing Countries-2016. Policy paper, International Monetary Fund, Washington, DC.

Jordà, Ò., Schularick, M., and Taylor, A. M. (2011). Financial Crises, Credit Booms, and External Imbalances: 140 Years of Lessons. IMF Economic Review, 59(2):340-378.

Jordà, Ò., Schularick, M., and Taylor, A. M. (2013). When Credit Bites Back. Journal of Money, Credit and Banking, 45(s2):3-28.

Jordà, Ò., Schularick, M., and Taylor, A. M. (2015). Leveraged bubbles. Journal of Monetary Economics, 76:S1-S20.

Jordà, Ò., Schularick, M., and Taylor, A. M. (2016). Sovereigns Versus Banks: Credit, Crises, And Consequences. Journal of the European Economic Association, 14(1):45-79.

Kaminsky, G. L. and Reinhart, C. M. (1999). The twin crises: The causes of banking and balanceof-payments problems. American Economic Review, 89(3):473-500.

Kauko, K. (2014). How to foresee banking crises? A survey of the empirical literature. Economic Systems, 38(3):289-308.

Kinda, T., Mlachila, M., et al. (2016). Commodity Price Shocks and Financial Sector Fragility. IMF Working Paper 16/12, International Monetary Fund, Washington DC.

King, G. and Zeng, L. (2001). Logistic regression in rare events data. Political analysis, 9(2):137-163.

Klomp, J. (2010). Causes of banking crises revisited. The North American Journal of Economics and Finance, 21(1):72-87. 
Laeven, L. and Valencia, F. (2013). Systemic banking crises database. IMF Economic Review, $61: 225-270$.

Mendoza, E. G. (1997). Terms-of-trade uncertainty and economic growth. Journal of Development Economics, 54(2):323-356.

Mundlak, Y. (1978). On the pooling of time series and cross section data. Econometrica, 46(1):6985.

Neyman, J. and Scott, E. L. (1948). Consistent Estimates Based on Partially Consistent Observations. Econometrica, 16(1):1-32.

Papi, L., Presbitero, A. F., and Zazzaro, A. (2015). IMF Lending and Banking Crises. IMF Economic Review, 63(3):644-691.

Park, J. Y. and Phillips, P. C. B. (2000). Nonstationary Binary Choice. Econometrica, 68(5):12491280.

Raddatz, C. (2007). Are external shocks responsible for the instability of output in low-income countries? Journal of Development Economics, 84(1):155-187.

Reinhart, C. M., Reinhart, V. R., and Trebesch, C. (2016). Global Cycles: Capital Flows, Commodities, and Sovereign Defaults, 1815-2015. American Economic Review, 106(5):574-580.

Reinhart, C. M. and Rogoff, K. S. (2011). From financial crash to debt crisis. American Economic Review, 101(5):1676-1706.

Reinhart, C. M. and Rogoff, K. S. (2013). Banking crises: An equal opportunity menace. Journal of Banking \& Finance, 37(11):4557-4573.

Rousseau, P. L. and Wachtel, P. (2011). What is happening to the impact of financial deepening on economic growth? Economic Inquiry, 49(1):276-288.

Schularick, M. and Taylor, A. M. (2012). Credit booms gone bust: Monetary policy, leverage cycles, and financial crises, 1870-2008. American Economic Review, 102(2):1029-61. 
Von Hagen, J. and Ho, T.-K. (2007). Money market pressure and the determinants of banking crises. Journal of Money, Credit and Banking, 39(5):1037-1066. 
Figures and Tables

Figure 1: Banking Crises - Frequency Analysis (1981-2015)

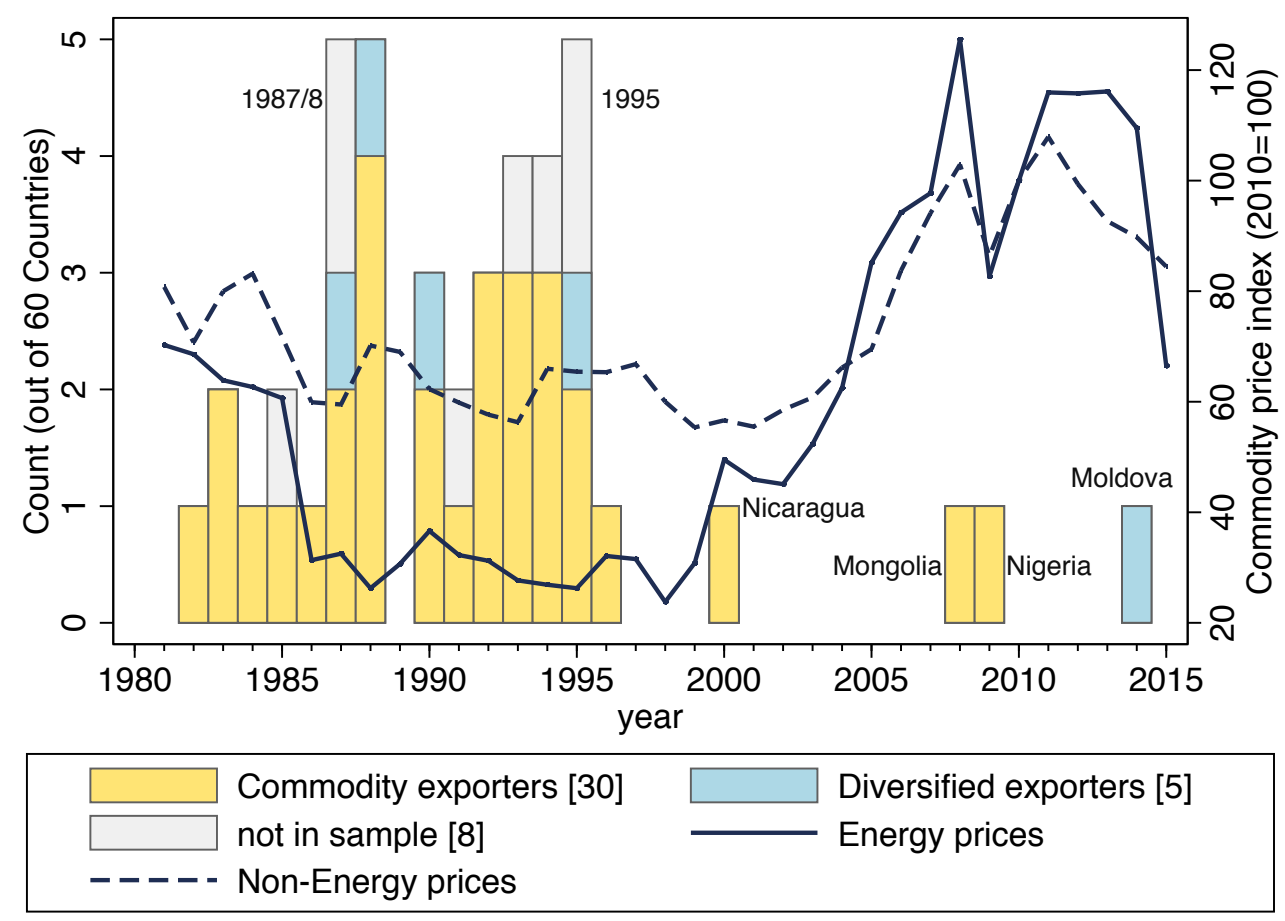

Notes: $N=60$ PRGT-eligible economies, 'in sample' refers to crises captured in our regression analysis. The sample covers the period 1981-2015; 29 countries in our sample experienced crises.

Figure 2: Aggregate Commodity Price Growth

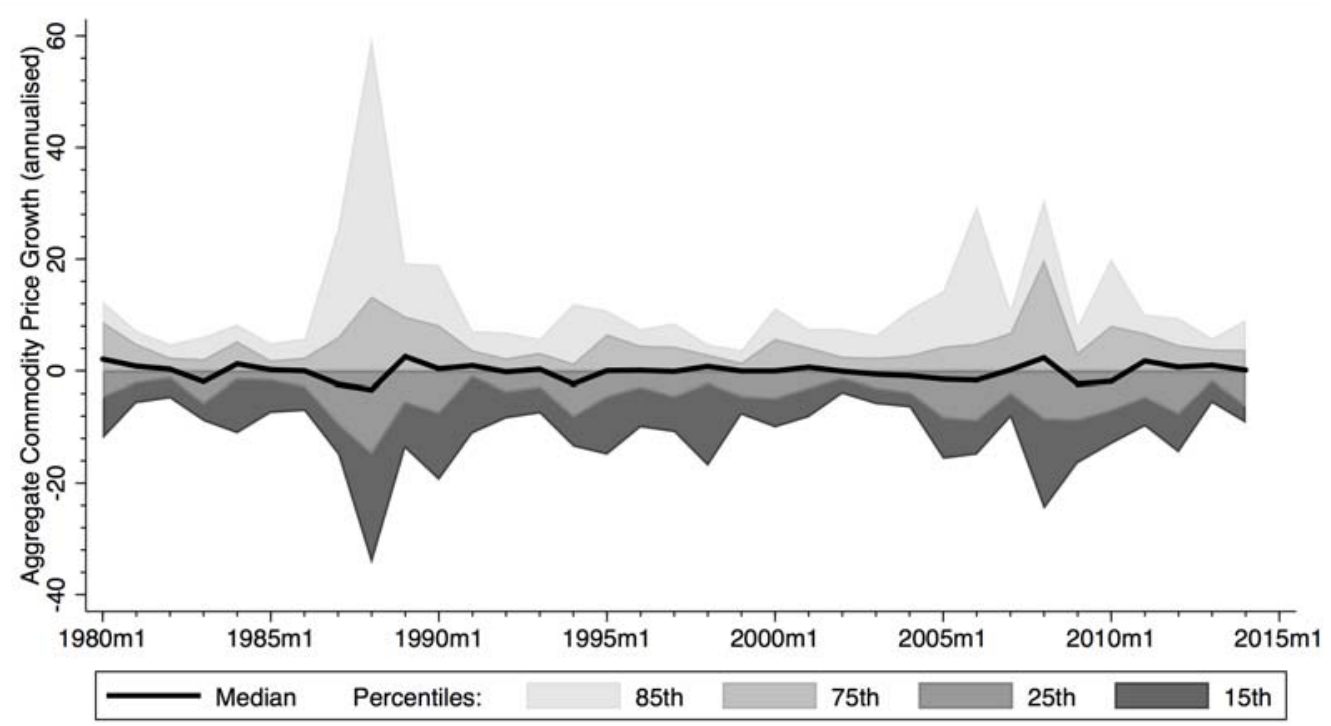

Notes: Annualised aggregate commodity price growth (median and various percentiles; multiplied by 100 ) for $N=60$ PRGT-eligible economies. The monthly sample covers the period 1981-2016, the (fixed) weights used to aggregate the individual commodity price series are the net export/GDP means over the entire time horizon. This means the shocks observed are not due to trade collapses/booms in specific years but due to price collapses/booms. 
Figure 3: Banking Crises - Event Analysis
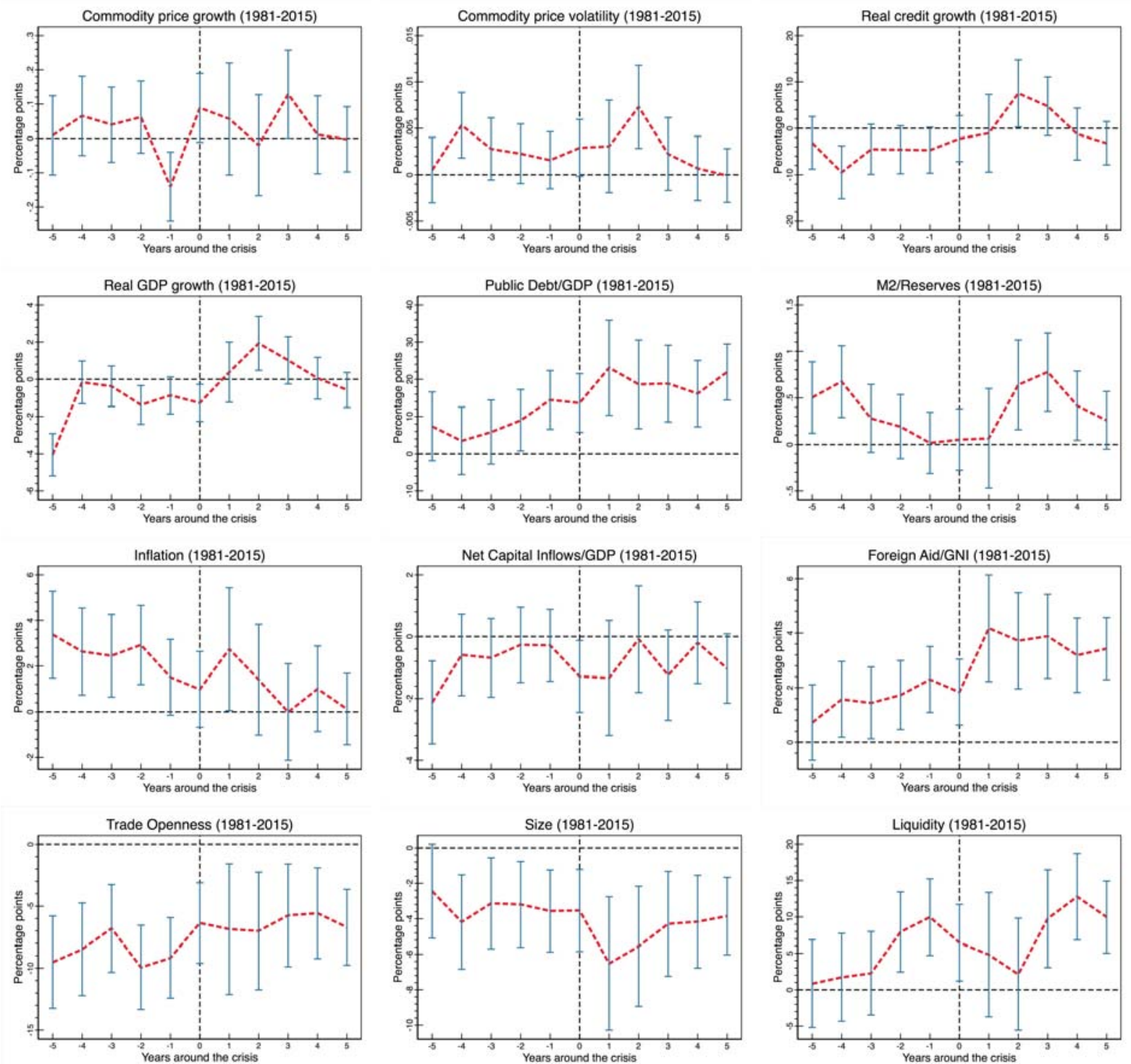

Notes: We present selected event analysis plots for the period 1981-2015. The estimates are derived from crisis dummy lags and leads in a pooled robust regression with country fixed effects, see equation (2), with $90 \%$ confidence intervals (blue bars). Note that the samples analysed exclude ongoing crisis years (as is standard in the literature). All variables are winsorized but in contrast to the data used in the regressions there is no MA(3) transformation carried out here. 
Figure 4: ROC Plots

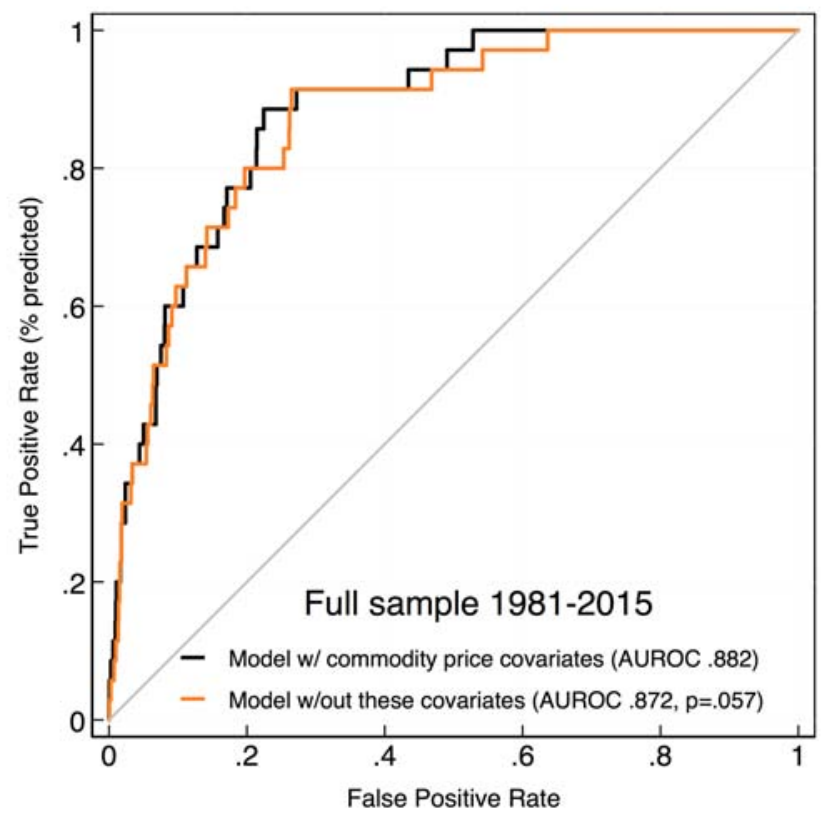

(a) Comparing Models with and without Commodity Price Variables

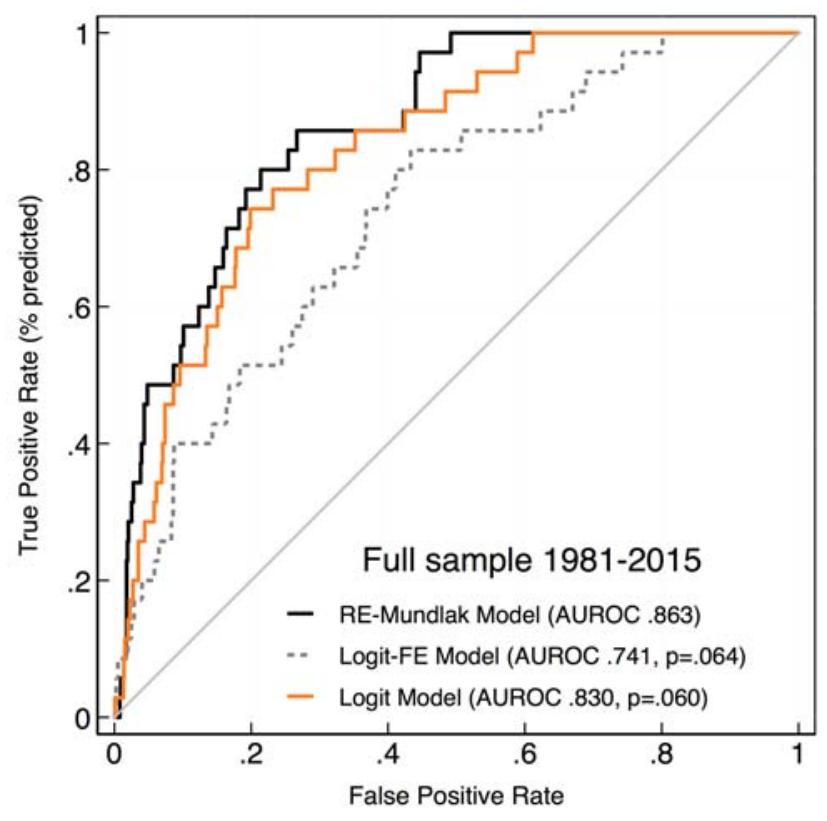

(b) Comparing Estimators for the Full Model

Notes: We chart the ROC curves for various empirical models. In panel (a) we compare the model with (black line) and without (orange line) commodity price variables for the full sample (specification in column (4) of Table 1). In panel (b) we compare the model with commodity price variables for three estimators: (i) a pooled logit model (orange line), (ii) a FE Logit model (dashed grey line), and (iii) the RE-Mundlak model (black line). Note that the FE Logit model has a smaller sample (only including countries with at least one banking crisis). Reported $p$-values here indicate statistically significant increase in predictive power of the model between the RE-Mundlak benchmark and the alternative models. 
Table 1: Main Results - Economic Magnitudes (1sd increase in covariate)

\begin{tabular}{|c|c|c|c|c|c|c|}
\hline \multirow[b]{2}{*}{$\begin{array}{l}\text { Unconditional Crisis Probability } \\
\text { DV: Crisis Start Year }\end{array}$} & \multicolumn{4}{|c|}{ RE-Mundlak Logit } & \multirow{2}{*}{$\begin{array}{l}\text { Logit } \\
2.3 \% \\
(5)\end{array}$} & \multirow{2}{*}{$\begin{array}{c}\text { FE Logit } \\
4.3 \% \\
(6)\end{array}$} \\
\hline & $\begin{array}{l}2.3 \% \\
(1)\end{array}$ & $\begin{array}{l}2.3 \% \\
(2)\end{array}$ & $\begin{array}{l}2.3 \% \\
(3)\end{array}$ & $\begin{array}{l}2.3 \% \\
(4)\end{array}$ & & \\
\hline \multicolumn{7}{|c|}{ Selected Covariates (in percent, winsorized, MA(3) transformed) } \\
\hline Commodity Price Growth & $\begin{array}{r}-0.622 \\
(3.05)^{* * *}\end{array}$ & $\begin{array}{r}-1.046 \\
(3.30)^{* * *}\end{array}$ & $\begin{array}{r}-0.836 \\
(2.53)^{* *}\end{array}$ & $\begin{array}{r}-1.381 \\
(2.28)^{* *}\end{array}$ & $\begin{array}{r}-1.026 \\
(2.82)^{* * *}\end{array}$ & $\begin{array}{l}-6.859 \\
(0.41)\end{array}$ \\
\hline $\begin{array}{l}\text { Commodity Price } \\
\text { Growth Volatility }\end{array}$ & $\begin{array}{r}1.964 \\
(2.37)^{* *}\end{array}$ & $\begin{array}{r}1.463 \\
(2.68)^{* * *}\end{array}$ & $\begin{array}{r}1.577 \\
(1.46)\end{array}$ & $\begin{array}{r}0.710 \\
(0.37)\end{array}$ & $\begin{array}{l}-0.624 \\
(1.32)\end{array}$ & $\begin{array}{r}1.734 \\
(0.06)\end{array}$ \\
\hline Real GDP Growth & & & $\begin{array}{r}0.638 \\
(1.18)\end{array}$ & $\begin{array}{r}0.445 \\
(0.83)\end{array}$ & $\begin{array}{l}-0.087 \\
(0.22)\end{array}$ & $\begin{array}{r}1.702 \\
(0.57)\end{array}$ \\
\hline Change in Credit/GDP & & & $\begin{array}{r}0.699 \\
(0.83)\end{array}$ & $\begin{array}{r}1.001 \\
(1.01)\end{array}$ & $\begin{array}{r}0.343 \\
(0.52)\end{array}$ & $\begin{array}{r}6.627 \\
(1.08)\end{array}$ \\
\hline M2/Reserves & & & $\begin{array}{r}1.049 \\
(2.47)^{* *}\end{array}$ & $\begin{array}{r}1.124 \\
(2.63)^{* * *}\end{array}$ & $\begin{array}{r}0.536 \\
(2.32)^{* *}\end{array}$ & $\begin{array}{r}8.568 \\
(1.21)\end{array}$ \\
\hline Public Debt/GDP & & & $\begin{array}{r}0.688 \\
(1.19)\end{array}$ & $\begin{array}{r}0.116 \\
(0.19)\end{array}$ & $\begin{array}{r}0.088 \\
(0.25)\end{array}$ & $\begin{array}{r}0.658 \\
(0.54)\end{array}$ \\
\hline Inflation & & & $\begin{array}{r}1.182 \\
(1.62)\end{array}$ & $\begin{array}{r}1.498 \\
(1.71)^{*}\end{array}$ & $\begin{array}{r}0.766 \\
(1.36)\end{array}$ & $\begin{array}{r}42.280 \\
(1.47)\end{array}$ \\
\hline Net Capital Inflows/GDP & & & & $\begin{array}{r}0.992 \\
(2.30)^{* *}\end{array}$ & $\begin{array}{r}0.347 \\
(0.71)\end{array}$ & $\begin{array}{r}20.181 \\
(1.16)\end{array}$ \\
\hline Foreign Aid/GNI & & & & $\begin{array}{r}2.122 \\
(3.25)^{* * *}\end{array}$ & $\begin{array}{r}0.441 \\
(1.22)\end{array}$ & $\begin{array}{r}6.143 \\
(1.65)^{*}\end{array}$ \\
\hline Trade Openness & & & & $\begin{array}{r}-2.592 \\
(2.60)^{* * *}\end{array}$ & $\begin{array}{l}-0.823 \\
(1.84)^{*}\end{array}$ & $\begin{array}{r}-4.277 \\
(0.93)\end{array}$ \\
\hline \multicolumn{7}{|l|}{ Additional Covariate Groups } \\
\hline 10-yr US Treasury Rate eoy & $x$ & $x$ & $x$ & $x$ & $x$ & $x$ \\
\hline Deposit Insurance \& Crisis Dummies & $x$ & $x$ & $x$ & $x$ & $x$ & $x$ \\
\hline Banking System & & $\times$ & $\times$ & $\times$ & $\times$ & $\times$ \\
\hline Observations & 1,550 & 1,550 & 1,550 & 1,550 & 1,550 & 804 \\
\hline Countries & 60 & 60 & 60 & 60 & 60 & 29 \\
\hline Crises & 35 & 35 & 35 & 35 & 35 & 35 \\
\hline LogL & -148.20 & -143.38 & -135.21 & -127.15 & -141.40 & -84.05 \\
\hline AUROC & 0.799 & 0.822 & 0.858 & 0.882 & 0.829 & 0.748 \\
\hline $\operatorname{se}(A U R O C)$ & 0.028 & 0.026 & 0.025 & 0.024 & 0.030 & 0.041 \\
\hline ROC Comparison & & (2) vs (1) & (3) vs (1) & (4) vs (3) & (5) vs (4) & (6) vs (4) \\
\hline ROC Comp $p$-value & & 0.230 & 0.008 & 0.103 & 0.007 & 0.024 \\
\hline Wald $\chi^{2}(\mathrm{FE})$ & 13.55 & 16.05 & 42.66 & 72.98 & & \\
\hline Wald $p$-value & 0.035 & 0.042 & 0.000 & 0.000 & & \\
\hline
\end{tabular}

Notes: All estimates shown are the economic magnitudes for a one standard deviation increase in the explanatory variable, expressed in percent. Absolute $t$-ratios in parentheses, based on standard errors computed via the Delta method from logit estimates (where in turn standard errors based on clustering at the country level). ${ }^{*},{ }^{* *}$ and ${ }^{* * *}$ indicate statistical significance at the $10 \%, 5 \%$ and $1 \%$ level, respectively. Additional covariate groups: 'Deposit Insurance \& Crisis Dummies' - fiscal crisis dummy, currency crisis dummy, deposit insurance dummy; 'Banking System' - liquidity, size. 
Table 2: Robustness checks - Economic Magnitudes - RE-Mundlak Logit Regressions

\begin{tabular}{|c|c|c|c|c|c|}
\hline DV: Crisis Year dummy & $(1)$ & $(2)$ & (3) & $(4)$ & $(5)$ \\
\hline Unconditional Crisis Probability & $2.3 \%$ & $2.3 \%$ & $2.2 \%$ & $4.2 \%$ & $2.3 \%$ \\
\hline Sample includes/transformation ${ }^{\ddagger}$ & - & No small $T$ & ongoing & $1980 s / 90 s$ & CS-DM \\
\hline \multicolumn{6}{|c|}{ Selected Covariates (in percent, winsorized, $M A(3)$ ) } \\
\hline Commodity Price Growth & $\begin{array}{r}-1.381 \\
(2.28)^{* *}\end{array}$ & $\begin{array}{l}-1.153 \\
(1.88)^{*}\end{array}$ & $\begin{array}{r}-1.348 \\
(2.65)^{* * *}\end{array}$ & $\begin{array}{l}-1.987 \\
(1.91)^{*}\end{array}$ & $\begin{array}{r}-0.990 \\
(3.13)^{* * *}\end{array}$ \\
\hline $\begin{array}{l}\text { Commodity Price } \\
\text { Growth Volatility }\end{array}$ & $\begin{array}{r}0.710 \\
(0.37)\end{array}$ & $\begin{array}{r}0.277 \\
(0.26)\end{array}$ & $\begin{array}{r}0.460 \\
(0.28)\end{array}$ & $\begin{array}{r}0.538 \\
(0.37)\end{array}$ & $\begin{array}{r}2.097 \\
(1.22)\end{array}$ \\
\hline Real GDP Growth & $\begin{array}{r}0.445 \\
(0.83)\end{array}$ & $\begin{array}{r}0.525 \\
(0.95)\end{array}$ & $\begin{array}{r}0.451 \\
(0.93)\end{array}$ & $\begin{array}{r}0.188 \\
(0.18)\end{array}$ & $\begin{array}{r}0.197 \\
(0.37)\end{array}$ \\
\hline Change in Credit/GDP & $\begin{array}{r}1.001 \\
(1.01)\end{array}$ & $\begin{array}{r}1.384 \\
(1.34)\end{array}$ & $\begin{array}{r}0.708 \\
(0.84)\end{array}$ & $\begin{array}{l}2.263 \\
(0.98)\end{array}$ & $\begin{array}{r}0.654 \\
(0.75)\end{array}$ \\
\hline M2/Reserves & $\begin{array}{r}1.124 \\
(2.63)^{* * *}\end{array}$ & $\begin{array}{r}1.213 \\
(2.61)^{* * *}\end{array}$ & $\begin{array}{r}0.975 \\
(2.89)^{* * *}\end{array}$ & $\begin{array}{r}2.736 \\
(2.47)^{* *}\end{array}$ & $\begin{array}{r}0.722 \\
(1.78)^{*}\end{array}$ \\
\hline Public Debt/GDP & $\begin{array}{r}0.116 \\
(0.19)\end{array}$ & $\begin{array}{r}0.104 \\
(0.17)\end{array}$ & $\begin{array}{r}0.034 \\
(0.06)\end{array}$ & $\begin{array}{l}-0.403 \\
(0.21)\end{array}$ & $\begin{array}{r}0.659 \\
(0.94)\end{array}$ \\
\hline Inflation & $\begin{array}{r}1.498 \\
(1.71)^{*}\end{array}$ & $\begin{array}{r}1.894 \\
(2.04)^{* *}\end{array}$ & $\begin{array}{r}1.289 \\
(1.72)^{*}\end{array}$ & $\begin{array}{r}3.478 \\
(1.49)\end{array}$ & $\begin{array}{r}1.180 \\
(1.52)\end{array}$ \\
\hline Net Capital Inflows/GDP & $\begin{array}{r}0.992 \\
(2.30)^{* *}\end{array}$ & $\begin{array}{r}1.008 \\
(2.38)^{* *}\end{array}$ & $\begin{array}{r}1.035 \\
(2.29)^{* *}\end{array}$ & $\begin{array}{r}2.590 \\
(3.32)^{* * *}\end{array}$ & $\begin{array}{r}0.951 \\
(2.09)^{* *}\end{array}$ \\
\hline Foreign Aid/GNI & $\begin{array}{r}2.122 \\
(3.25)^{* * *}\end{array}$ & $\begin{array}{r}2.279 \\
(3.47)^{* * *}\end{array}$ & $\begin{array}{r}1.844 \\
(2.95)^{* * *}\end{array}$ & $\begin{array}{r}3.219 \\
(2.53)^{* *}\end{array}$ & $\begin{array}{r}0.486 \\
(0.55)\end{array}$ \\
\hline Trade Openness & $\begin{array}{r}-2.592 \\
(2.60)^{* * *} \\
\end{array}$ & $\begin{array}{r}-2.808 \\
(2.66)^{* * *} \\
\end{array}$ & $\begin{array}{r}-2.559 \\
(3.01)^{* * *} \\
\end{array}$ & $\begin{array}{r}-5.445 \\
(2.20)^{* *} \\
\end{array}$ & $\begin{array}{l}-1.437 \\
(1.57) \\
\end{array}$ \\
\hline \multicolumn{6}{|l|}{ Additional Covariate Groups } \\
\hline Deposit Insurance \& Crisis Dummies & $\times$ & $\times$ & $\times$ & $\times$ & $x$ \\
\hline 10-yr US Treasury Rate eoy & $\times$ & $\times$ & $x$ & $\times$ & $x$ \\
\hline Banking System & $\times$ & $\times$ & $x$ & $\times$ & $x$ \\
\hline Observations & 1,550 & 1,455 & 1,619 & 759 & 1,550 \\
\hline Countries & 60 & 52 & 60 & 54 & 60 \\
\hline Crises & 35 & 33 & 35 & 32 & 35 \\
\hline $\operatorname{LogL}$ & -127.15 & -120.16 & -131.54 & -106.14 & -139.49 \\
\hline AUROC & 0.882 & 0.877 & 0.873 & 0.838 & 0.834 \\
\hline se(AUROC) & 0.024 & 0.027 & 0.023 & 0.034 & 0.033 \\
\hline Wald $\chi^{2}(\mathrm{FE})$ & 72.98 & 69.95 & 81.55 & 38.94 & 0.186 \\
\hline Wald $p$-value & 0.000 & 0.000 & 0.000 & 0.001 & 49.95 \\
\hline
\end{tabular}

Notes: $\ddagger$ We compare results for different samples with the benchmark model from column (4) in Table 1: (a) drop countries with 15 observations or fewer (column 2); (b) re-introduce observations for 'ongoing' banking crisis years (column 3); (c) limit sample to 1981-2000 (column 4); and (d) take all variables in deviation from the cross-section mean $\left(\tilde{x}_{i t}=x_{i t}-x_{t}\right.$, column 5$)$. In all cases we report marginal effects using the same definition (magnitudes, standard errors, etc.) as in Table 1 . See Table 1 for details on additional covariate groups and diagnostic tests. 
Table 3: Alternative MA-transformation - Economic Magnitudes

\begin{tabular}{|c|c|c|c|c|c|}
\hline \multirow[b]{2}{*}{ DV: Crisis Start Year } & \multicolumn{5}{|c|}{ RE-Mundlak Logit } \\
\hline & $(1)$ & $(2)$ & (3) & $(4)$ & (5) \\
\hline MA-transformation & Lagged & $\mathrm{MA}(2)$ & $\mathrm{MA}(3)$ & $\mathrm{MA}(4)$ & $\mathrm{MA}(5)$ \\
\hline \multicolumn{6}{|c|}{ Selected Covariates (in percent, winsorized, MA-transformed or lagged) } \\
\hline Commodity Price Growth & $\begin{array}{r}-0.942 \\
(3.12)^{* * *}\end{array}$ & $\begin{array}{r}-0.506 \\
(1.62)\end{array}$ & $\begin{array}{r}-1.381 \\
(2.28)^{* *}\end{array}$ & $\begin{array}{r}-1.705 \\
(4.52)^{* * *}\end{array}$ & $\begin{array}{r}-2.214 \\
(3.43)^{* * *}\end{array}$ \\
\hline $\begin{array}{l}\text { Commodity Price } \\
\text { Growth Volatility }\end{array}$ & $\begin{array}{l}-6.875 \\
(1.94)^{*}\end{array}$ & $\begin{array}{l}-4.505 \\
(1.94)^{*}\end{array}$ & $\begin{array}{r}0.710 \\
(0.37)\end{array}$ & $\begin{array}{r}0.833 \\
(0.87)\end{array}$ & $\begin{array}{r}4.564 \\
(2.18)^{* *}\end{array}$ \\
\hline Real GDP Growth & $\begin{array}{r}0.646 \\
(1.53)\end{array}$ & $\begin{array}{r}0.433 \\
(0.96)\end{array}$ & $\begin{array}{r}0.445 \\
(0.83)\end{array}$ & $\begin{array}{r}0.940 \\
(1.95)^{*}\end{array}$ & $\begin{array}{r}0.469 \\
(1.06)\end{array}$ \\
\hline Change in Credit/GDP & $\begin{array}{r}1.592 \\
(3.20)^{* * *}\end{array}$ & $\begin{array}{r}1.945 \\
(2.48)^{* *}\end{array}$ & $\begin{array}{r}1.001 \\
(1.01)\end{array}$ & $\begin{array}{r}0.938 \\
(0.81)\end{array}$ & $\begin{array}{r}1.409 \\
(1.35)\end{array}$ \\
\hline sM2/Reserves & $\begin{array}{r}1.140 \\
(3.39)^{* * *}\end{array}$ & $\begin{array}{r}1.080 \\
(3.19)^{* * *}\end{array}$ & $\begin{array}{r}1.124 \\
(2.63)^{* * *}\end{array}$ & $\begin{array}{r}1.242 \\
(2.71)^{* * *}\end{array}$ & $\begin{array}{r}0.863 \\
(2.32)^{* *}\end{array}$ \\
\hline Public Debt/GDP & $\begin{array}{r}0.760 \\
(1.54)\end{array}$ & $\begin{array}{r}0.136 \\
(0.26)\end{array}$ & $\begin{array}{r}0.116 \\
(0.19)\end{array}$ & $\begin{array}{l}-0.228 \\
(0.32)\end{array}$ & $\begin{array}{r}0.039 \\
(0.05)\end{array}$ \\
\hline Inflation & $\begin{array}{r}1.604 \\
(3.52)^{* * *}\end{array}$ & $\begin{array}{r}2.433 \\
(3.23)^{* * *}\end{array}$ & $\begin{array}{r}1.498 \\
(1.71)^{*}\end{array}$ & $\begin{array}{r}1.872 \\
(1.68)^{*}\end{array}$ & $\begin{array}{r}1.894 \\
(1.96)^{*}\end{array}$ \\
\hline Net Capital Inflows/GDP & $\begin{array}{r}0.593 \\
(1.47)\end{array}$ & $\begin{array}{r}1.197 \\
(2.48)^{* *}\end{array}$ & $\begin{array}{r}0.992 \\
(2.30)^{* *}\end{array}$ & $\begin{array}{r}0.996 \\
(2.39)^{* *}\end{array}$ & $\begin{array}{r}0.629 \\
(1.31)\end{array}$ \\
\hline Foreign Aid/GNI & $\begin{array}{r}1.318 \\
(2.59)^{* * *}\end{array}$ & $\begin{array}{r}2.075 \\
(3.44)^{* * *}\end{array}$ & $\begin{array}{r}2.122 \\
(3.25)^{* * *}\end{array}$ & $\begin{array}{r}2.547 \\
(3.76)^{* * *}\end{array}$ & $\begin{array}{r}1.922 \\
(2.76)^{* * *}\end{array}$ \\
\hline Trade Openness & $\begin{array}{l}-0.517 \\
(0.42)\end{array}$ & $\begin{array}{r}-2.467 \\
(2.18)^{* *}\end{array}$ & $\begin{array}{r}-2.592 \\
(2.60)^{* * *}\end{array}$ & $\begin{array}{r}-3.526 \\
(3.39)^{* * *}\end{array}$ & $\begin{array}{r}-3.886 \\
(3.76)^{* * *}\end{array}$ \\
\hline \multicolumn{6}{|l|}{ Additional Covariate Groups } \\
\hline Deposit Insurance \& Crisis Dummies & $x$ & $x$ & $x$ & $x$ & $x$ \\
\hline 10-yr US Treasury Rate eoy & $x$ & $x$ & $x$ & $x$ & $x$ \\
\hline Banking System & $\times$ & $\times$ & $\times$ & $\times$ & $x$ \\
\hline Observations & 1,476 & 1,523 & 1,550 & 1,569 & 1,584 \\
\hline Countries & 60 & 60 & 60 & 60 & 60 \\
\hline Crises & 35 & 35 & 35 & 36 & 36 \\
\hline $\log \mathrm{L}$ & -129.52 & -128.19 & -127.15 & -124.43 & -127.18 \\
\hline AUROC & 0.860 & 0.866 & 0.882 & 0.898 & 0.896 \\
\hline se(AUROC) & 0.029 & 0.029 & 0.024 & 0.024 & 0.018 \\
\hline Wald $\chi^{2}(\mathrm{FE})$ & 48.39 & 61.59 & 72.98 & 48.48 & 53.52 \\
\hline Wald $p$-value & 0.000 & 0.000 & 0.000 & 0.000 & 0.000 \\
\hline
\end{tabular}

Notes: We present marginal effects (1sd increase in covariate) for the main empirical model (model (4) from Table 1) adopting different MA-transformations for the data. In all cases the variable values at $t-1$ and $t-2$ are included, for $\mathrm{MA}(3)$ we furher add $t-3$, for $\mathrm{MA}(4) t-4$, and for $\mathrm{MA}(5) t-5$. The model in (1) simply lags all regressors by one period, which is a widespread practice in the literature. Absolute $t$-ratios in parentheses. ${ }^{*},{ }^{* *}$ and ${ }^{* * *}$ indicate statistical significance at the $10 \%, 5 \%$ and $1 \%$ level, respectively. 
Table 4: The Role of Leverage - Economic Magnitudes

\begin{tabular}{|c|c|c|c|c|c|}
\hline \multirow[b]{2}{*}{ DV: Crisis Start Year } & \multicolumn{5}{|c|}{ RE-Mundlak Logit } \\
\hline & $(1)$ & $(2)$ & (3) & $(4)$ & (5) \\
\hline \multicolumn{6}{|c|}{ Selected Covariates (in percent, winsorized, MA(3)) } \\
\hline Commodity Price Growth & & & & & $\begin{array}{r}-1.381 \\
(2.28)^{* *}\end{array}$ \\
\hline $\begin{array}{l}\text { Commodity Price } \\
\text { Growth Volatility }\end{array}$ & & & & & $\begin{array}{r}0.710 \\
(0.37)\end{array}$ \\
\hline Real GDP Growth & & & & $\begin{array}{r}0.430 \\
(0.82)\end{array}$ & $\begin{array}{r}0.445 \\
(0.83)\end{array}$ \\
\hline Growth in Credit/GDP & $\begin{array}{r}-0.546 \\
\dagger\end{array}$ & $\begin{array}{c}-0.556 \\
(1.95)^{*}\end{array}$ & $\begin{array}{r}0.751 \\
(0.92)\end{array}$ & $\begin{array}{r}1.026 \\
(1.06)\end{array}$ & $\begin{array}{r}1.001 \\
(1.01)\end{array}$ \\
\hline M2/Reserves & & & $\begin{array}{r}1.025 \\
(2.36)^{* *}\end{array}$ & $\begin{array}{r}1.186 \\
(2.84)^{* * *}\end{array}$ & $\begin{array}{r}1.124 \\
(2.63) * * *\end{array}$ \\
\hline Public Debt/GDP & & & $\begin{array}{r}0.798 \\
(1.42)\end{array}$ & $\begin{array}{r}0.220 \\
(0.37)\end{array}$ & $\begin{array}{r}0.116 \\
(0.19)\end{array}$ \\
\hline Inflation & & & $\begin{array}{r}1.234 \\
(1.68)^{*}\end{array}$ & $\begin{array}{r}1.573 \\
(1.77)^{*}\end{array}$ & $\begin{array}{r}1.498 \\
(1.71)^{*}\end{array}$ \\
\hline Net Capital Inflows/GDP & & & & $\begin{array}{r}1.112 \\
(2.15)^{* *}\end{array}$ & $\begin{array}{r}0.992 \\
(2.30)^{* *}\end{array}$ \\
\hline Official development assistance/GNI & & & & $\begin{array}{r}2.094 \\
(3.00)^{* * *}\end{array}$ & $\begin{array}{r}2.122 \\
(3.25)^{* * *}\end{array}$ \\
\hline Trade Openness & & & & $\begin{array}{r}-2.151 \\
(2.36)^{* *}\end{array}$ & $\begin{array}{r}-2.592 \\
(2.60)^{* * *}\end{array}$ \\
\hline \multicolumn{6}{|l|}{ Additional Covariate Groups } \\
\hline Deposit Insurance \& Crisis Dummies & $\times$ & $x$ & $\times$ & $\times$ & $x$ \\
\hline 10-yr US Treasury Rate eoy & $x$ & $x$ & $\times$ & $\times$ & $x$ \\
\hline Banking System & & $\times$ & $\times$ & $\times$ & $x$ \\
\hline Observations & 1,550 & 1,550 & 1,550 & 1,550 & 1,550 \\
\hline Countries & 60 & 60 & 60 & 60 & 60 \\
\hline Crises & 35 & 35 & 35 & 35 & 35 \\
\hline $\log L$ & -149.80 & -145.92 & -137.72 & -130.18 & -127.15 \\
\hline AUROC & 0.774 & 0.801 & 0.842 & 0.872 & 0.882 \\
\hline $\operatorname{se}(A U R O C)$ & 0.032 & 0.029 & 0.027 & 0.027 & 0.024 \\
\hline ROC Comparison & & (2) vs (1) & (3) vs (1) & (4) vs (1) & (4) vs (5) \\
\hline ROC Comp $p$-value & & 0.141 & 0.013 & 0.001 & 0.057 \\
\hline Wald $\chi^{2}(\mathrm{FE})$ & 2.50 & 6.30 & 31.95 & 58.72 & 72.98 \\
\hline Wald $p$-value & 0.777 & 0.505 & 0.001 & 0.000 & 0.000 \\
\hline
\end{tabular}

Notes: Estimates reported are economic magnitudes as in Tables 1 and 2. Absolute $t$-ratios in parentheses based on standard errors computed via the delta method - $\dagger$ possibly due to the parsimony of the estimation equation we could not obtain standard errors for the marginal effects of the model in (1). ${ }^{*},{ }^{* *}$ and ${ }^{* * *}$ indicate statistical significance at the $10 \%, 5 \%$ and $1 \%$ level, respectively. 
Table 5: Credit Bonanzas and Surges - Raw Logit Coefficients

\begin{tabular}{|c|c|c|c|c|c|c|c|}
\hline \multirow[t]{2}{*}{ DV: Crisis Start Year dummy } & (1) & $(2)$ & (3) & (4) & $(5)$ & (6) & (7) \\
\hline & - & \multicolumn{2}{|c|}{ Credit Bonanzas } & \multicolumn{4}{|c|}{ Credit Surges } \\
\hline Definition $^{\dagger}$ & & $1 \mathrm{sd}$ & 1 sd & time $t$ & time $t$ & consec & consec \\
\hline Bonanza or Surge Count & & 11 & 11 & 311 & 311 & 298 & 298 \\
\hline \multicolumn{8}{|c|}{ Selected Covariates (in percent, winsorized, MA(3)) } \\
\hline Commodity Price Growth & $\begin{array}{r}-0.269 \\
(2.20)^{* *}\end{array}$ & $\begin{array}{l}-0.284 \\
(1.81)^{*}\end{array}$ & $\begin{array}{r}-0.302 \\
(1.98)^{* *}\end{array}$ & $\begin{array}{r}-0.295 \\
(2.40)^{* *}\end{array}$ & $\begin{array}{r}-0.308 \\
(2.73)^{* * *}\end{array}$ & $\begin{array}{r}-0.289 \\
(2.41)^{* *}\end{array}$ & $\begin{array}{r}-0.302 \\
(2.72)^{* * *}\end{array}$ \\
\hline $\begin{array}{l}\text { Commodity Price } \\
\text { Growth Volatility }\end{array}$ & $\begin{array}{r}0.308 \\
(0.37)\end{array}$ & $\begin{array}{r}0.185 \\
(0.22)\end{array}$ & $\begin{array}{r}0.200 \\
(0.26)\end{array}$ & $\begin{array}{r}0.099 \\
(0.13)\end{array}$ & $\begin{array}{r}0.108 \\
(0.16)\end{array}$ & $\begin{array}{r}0.158 \\
(0.20)\end{array}$ & $\begin{array}{r}0.169 \\
(0.24)\end{array}$ \\
\hline Credit/GDP Growth & $\begin{array}{r}0.024 \\
(1.01)\end{array}$ & $\begin{array}{r}0.030 \\
(1.29)\end{array}$ & & $\begin{array}{r}0.026 \\
(1.05)\end{array}$ & & $\begin{array}{r}0.028 \\
(1.11)\end{array}$ & \\
\hline Credit Bonanzas & & $\begin{array}{r}-1.709 \\
(0.55)\end{array}$ & $\begin{array}{l}-1.132 \\
(0.35)\end{array}$ & & & & \\
\hline Credit Surges & & & & $\begin{array}{r}0.855 \\
(0.97) \\
\end{array}$ & $\begin{array}{r}0.717 \\
(0.86) \\
\end{array}$ & $\begin{array}{r}1.134 \\
(1.48) \\
\end{array}$ & $\begin{array}{r}0.992 \\
(1.37) \\
\end{array}$ \\
\hline \multicolumn{8}{|l|}{ Additional Covariate Groups $\sharp$} \\
\hline Deposit Insurance \& Crisis Dummies & $x$ & $x$ & $x$ & $x$ & $x$ & $x$ & $x$ \\
\hline 10-yr US Treasury Rate eoy & $x$ & $x$ & $x$ & $x$ & $x$ & $x$ & $x$ \\
\hline Banking System & $x$ & $\times$ & $\times$ & $x$ & $x$ & $x$ & $x$ \\
\hline Trade, Aid \& Capital Flows & $\times$ & $x$ & $x$ & $\times$ & $x$ & $\times$ & $x$ \\
\hline Macro \& Monetary Fundamentals & $\times$ & $\times$ & $\times$ & $\times$ & $\times$ & $\times$ & $x$ \\
\hline Observations & 1,550 & 1,519 & 1,519 & 1,550 & 1,550 & 1,550 & 1,550 \\
\hline Countries & 60 & 60 & 60 & 60 & 60 & 60 & 60 \\
\hline Crises & 35 & 35 & 35 & 35 & 35 & 35 & 35 \\
\hline LogL & -127.15 & -124.42 & -125.50 & -126.12 & -126.95 & -125.75 & -126.67 \\
\hline AUROC & 0.882 & 0.887 & 0.883 & 0.884 & 0.881 & 0.885 & 0.883 \\
\hline se(AUROC) & 0.024 & 0.024 & 0.023 & 0.024 & 0.023 & 0.024 & 0.023 \\
\hline Wald $\chi^{2}(\mathrm{FE})$ & 72.98 & 80.71 & 79.07 & 82.47 & 80.54 & 78.57 & 80.75 \\
\hline Wald $p$-value & 0.000 & 0.000 & 0.000 & 0.000 & 0.000 & 0.000 & 0.000 \\
\hline
\end{tabular}

Notes: All estimates presented are raw logit coefficients. Absolute $t$-ratios in parentheses are based on standard errors clustered at the country-level. We compare results for the benchmark model (or rather its raw logit equivalent) from column (4) in Table 1 with a number of specifications for which the credit growth variable is replaced with a bonanza or surge dummy - for construction of these dummies see main text and below. Like all explanatory variables these dummies are MA(3) transformed. None of the models in (2)-(7) improve predictive power over the model (1) benchmark. $\dagger$ Definitions: 1sd - periods in which credit/GDP growth is one standard deviation above the country-specific (HPfiltered) trend; 2 sd - dto but two standard deviations above trend, but this only identified a single episode and is therefore not evaluated; time $t$ - surge is detected at time $t$; consec - surge is detected at times $t-1, t$, and $t+1$. The bonanzas are spread across 8 countries, the surges across 37 countries (for time $t$ and consec, respectively). $\sharp$ Additional covariate groups: 'Deposit Insurance \& Crisis Dummies' - deposit insurance, fiscal crisis and currency crisis dummies; 'Banking System' - liquidity, size; 'Trade, Aid \& Capital Flows' - net capital flows, trade openness, ODA/GNI; 'Macro \& Monetary Fundamentals' - real GDP growth, inflation, M2/Reserves, Debt/GDP ratio. 
Table 6: Capital Inflow Bonanzas and Surges - Raw Logit Coefficients

\begin{tabular}{|c|c|c|c|c|c|}
\hline \multirow[t]{2}{*}{ Panel A } & \multirow[t]{2}{*}{$(1)$} & $(2)$ & (3) & $(4)$ & $(5)$ \\
\hline & & \multicolumn{2}{|c|}{ Bonanzas } & \multicolumn{2}{|c|}{ Surges } \\
\hline Definition $^{\dagger}$ & - & $1 \mathrm{sd}$ & 2sd & time $t$ & consec \\
\hline Bonanza or Surge Count & - & 66 & 5 & 368 & 305 \\
\hline \multicolumn{6}{|c|}{ Selected Covariates (in percent, winsorized, MA(3)) } \\
\hline Commodity Price Growth & $\begin{array}{r}-0.287 \\
(2.47)^{* *}\end{array}$ & $\begin{array}{r}-0.256 \\
(2.32)^{* *}\end{array}$ & $\begin{array}{r}-0.269 \\
(2.37)^{* *}\end{array}$ & $\begin{array}{r}-0.269 \\
(2.69)^{* * *}\end{array}$ & $\begin{array}{r}-0.265 \\
(2.72)^{* * *}\end{array}$ \\
\hline $\begin{array}{l}\text { Commodity Price } \\
\text { Growth Volatility }\end{array}$ & $\begin{array}{r}0.325 \\
(0.41)\end{array}$ & $\begin{array}{r}0.354 \\
(0.48)\end{array}$ & $\begin{array}{r}0.293 \\
(0.40)\end{array}$ & $\begin{array}{r}0.378 \\
(0.50)\end{array}$ & $\begin{array}{r}0.467 \\
(0.59)\end{array}$ \\
\hline Net Capital Inflows/GDP & $\begin{array}{r}0.100 \\
(2.45)^{* *}\end{array}$ & & & & \\
\hline Capital flow bonanza & & $\begin{array}{l}-2.219 \\
(1.17)\end{array}$ & $\begin{array}{r}4.630 \\
(1.46)\end{array}$ & & \\
\hline Capital flow surge & & & & $\begin{array}{r}0.582 \\
(0.95)\end{array}$ & $\begin{array}{r}0.611 \\
(0.99) \\
\end{array}$ \\
\hline Observations & 1,550 & 1,550 & 1,550 & 1,550 & 1,550 \\
\hline Countries & 60 & 60 & 60 & 60 & 60 \\
\hline Crises & 35 & 35 & 35 & 35 & 35 \\
\hline LogL & -127.90 & -128.06 & -128.78 & -128.88 & -128.52 \\
\hline AUROC & 0.878 & 0.882 & 0.874 & 0.875 & 0.875 \\
\hline seAUROC & 0.023 & 0.022 & 0.023 & 0.023 & 0.024 \\
\hline Wald $\chi^{2}(\mathrm{FE})$ & 72.10 & 58.92 & 51.78 & 72.68 & 78.60 \\
\hline Wald $p$-value & 0.000 & 0.000 & 0.000 & 0.000 & 0.000 \\
\hline \multirow[t]{2}{*}{ Panel B } & (6) & (7) & (8) & (9) & $(10)$ \\
\hline & & \multicolumn{2}{|c|}{ Bonanzas } & \multicolumn{2}{|c|}{ Surges } \\
\hline Definition $^{\dagger}$ & - & $1 \mathrm{sd}$ & $2 s d$ & time $t$ & consec \\
\hline Bonanza/Surge Count: net FDI & & 60 & 14 & 368 & 305 \\
\hline Bonanza/Surge Count: net non- & lows & 84 & 13 & 359 & 236 \\
\hline \multicolumn{6}{|c|}{ Selected Covariates (in percent, winsorized, MA(3)) } \\
\hline Commodity Price Growth & $\begin{array}{r}-0.297 \\
(2.52)^{* *}\end{array}$ & $\begin{array}{r}-0.244 \\
(2.15)^{* *}\end{array}$ & $\begin{array}{r}-0.244 \\
(2.08)^{* *}\end{array}$ & $\begin{array}{r}-0.297 \\
(2.93)^{* * *}\end{array}$ & $\begin{array}{r}-0.282 \\
(2.85)^{* * *}\end{array}$ \\
\hline $\begin{array}{l}\text { Commodity Price } \\
\text { Growth Volatility }\end{array}$ & $\begin{array}{r}0.190 \\
(0.25)\end{array}$ & $\begin{array}{r}0.271 \\
(0.37)\end{array}$ & $\begin{array}{r}0.308 \\
(0.50)\end{array}$ & $\begin{array}{r}0.132 \\
(0.19)\end{array}$ & $\begin{array}{r}0.323 \\
(0.40)\end{array}$ \\
\hline Net FDI Inflows/GDP & $\begin{array}{r}0.086 \\
(0.73)\end{array}$ & & & & \\
\hline Net non-FDI Inflows/GDP & $\begin{array}{r}0.092 \\
(1.21)\end{array}$ & & & & \\
\hline Capital flow bonanza (FDI) & & $\begin{array}{r}0.294 \\
(0.15)\end{array}$ & $\begin{array}{r}1.811 \\
(0.75)\end{array}$ & & \\
\hline Capital flow bonanza (non-FDI) & & $\begin{array}{r}-6.370 \\
(1.97)^{* *}\end{array}$ & $\times$ & & \\
\hline Capital flow surge (FDI) & & & & $\begin{array}{r}1.569 \\
(1.56)\end{array}$ & $\begin{array}{r}1.683 \\
(1.55)\end{array}$ \\
\hline Capital flow surge (non-FDI) & & & & $\begin{array}{r}0.077 \\
(0.09)\end{array}$ & $\begin{array}{r}0.330 \\
(0.45)\end{array}$ \\
\hline Observations & 1,539 & 1,550 & 1,505 & 1,550 & 1,550 \\
\hline Countries & 60 & 60 & 60 & 60 & 60 \\
\hline Crises & 35 & 35 & 35 & 35 & 35 \\
\hline LogL & -126.65 & -121.18 & -127.53 & -126.78 & -127.34 \\
\hline AUROC & 0.884 & 0.899 & 0.875 & 0.881 & 0.880 \\
\hline seAUROC & 0.023 & 0.020 & 0.024 & 0.022 & 0.022 \\
\hline Wald $\chi^{2}(\mathrm{FE})$ & 69.67 & 133.65 & 68.14 & 79.58 & 80.83 \\
\hline Wald $p$-value & 0.000 & 0.000 & 0.000 & 0.000 & 0.000 \\
\hline
\end{tabular}

Notes: All estimates presented are raw logit coefficients. Absolute $t$-ratios in parentheses are based on standard errors clustered at the country-level. We compare results for the benchmark model (the raw logit equivalent) from column (4) in Table 1 with a number of specifications for which the net capital inflow/GDP variable (or a split variable for $\mathrm{FDI} /$ non-FDI inflows) is replaced with a bonanza or surge dummy. $†$ For definitions of surges and bonanzas see Table 5 , additional covariate groups are included in all models as discussed in the footnote to that Table. Including 'net capital inflows/GDP' in (2)-(5) and the FDI/non-FDI equivalent in (7)-(10) does not significantly change the patterns presented. $\times$ Due to their small number the non-FDI bonanzas perfectly identify absence of a crisis and are therefore dropped.

39

\section{CInternational Monetary Fund. Not for Redistribution}


Table 7: Focus on Alternative Regimes - Economic Magnitudes

\begin{tabular}{|c|c|c|c|c|c|}
\hline \multirow[b]{2}{*}{ DV: Crisis Start Year } & \multicolumn{5}{|c|}{ RE-Mundlak Logit } \\
\hline & (1) & (2) & (3) & (4) & (5) \\
\hline Regime & All & Fixed ER & Exporters & All & Comm \\
\hline Banking Crises in Regime & 35 & 23 & 14 & 35 & 12 \\
\hline Countries in Regime & 60 & 38 & 31 & 59 & 14 \\
\hline Observations in Regime & 1,550 & 1,157 & 826 & 1,516 & 349 \\
\hline Uncond. Crisis Prob in Regime & $2.3 \%$ & $2.0 \%$ & $1.7 \%$ & $2.3 \%$ & $3.4 \%$ \\
\hline Uncond. Crisis Prob in Base & & $3.1 \%$ & $2.9 \%$ & & $2.0 \%$ \\
\hline \multicolumn{6}{|c|}{ Selected Covariates (in percent, winsorized, MA(3)) } \\
\hline Commodity Price Growth & $\begin{array}{r}-1.062 \\
(2.10)^{* *}\end{array}$ & & & $\begin{array}{r}-1.099 \\
(2.11)^{* *}\end{array}$ & \\
\hline Base Category & & $\begin{array}{l}-2.571 \\
(1.41)\end{array}$ & $\begin{array}{l}-0.548 \\
(1.24)\end{array}$ & & $\begin{array}{l}-0.840 \\
(1.17)\end{array}$ \\
\hline Regime & & $\begin{array}{r}-1.190 \\
(2.16)^{* *} \\
\end{array}$ & $\begin{array}{r}-1.819 \\
(3.41)^{* * *} \\
\end{array}$ & & $\begin{array}{r}-1.499 \\
(3.06)^{* * *} \\
\end{array}$ \\
\hline \multicolumn{6}{|l|}{ Additional Covariate Groups } \\
\hline Deposit Insurance \& Crisis Dummies & $x$ & $\times$ & $x$ & $x$ & $x$ \\
\hline 10-yr US Treasury Rate eoy & $\times$ & $\times$ & $\times$ & $x$ & $\times$ \\
\hline Banking System & $\times$ & $\times$ & $x$ & $\times$ & $x$ \\
\hline Macro \& Monetary Fundamentals & $\times$ & $\times$ & $\times$ & $\times$ & $x$ \\
\hline Observations & 1,550 & 1,550 & 1,550 & 1,516 & 1,516 \\
\hline Countries & 60 & 60 & 60 & 59 & 59 \\
\hline Crises & 35 & 35 & 35 & 35 & 35 \\
\hline LogL & -128.62 & -128.24 & -128.29 & -128.60 & -128.39 \\
\hline AUROC & 0.875 & 0.878 & 0.877 & 0.872 & 0.873 \\
\hline se(AUROC) & 0.025 & 0.025 & 0.025 & 0.026 & 0.026 \\
\hline ROC Comparison & & (2) vs (1) & (3) vs (1) & & (5) vs (4) \\
\hline ROC Comp $p$-value & & 0.117 & 0.411 & & 0.579 \\
\hline Wald $\chi^{2}(\mathrm{FE})$ & 60.59 & 59.15 & & 58.97 & 54.97 \\
\hline Wald $p$-value & 0.000 & 0.000 & & 0.000 & 0.000 \\
\hline
\end{tabular}

Notes: We present marginal effects (1sd increase in covariate) for commodity price growth effects by ER regime, high/low export-share of GDP, and exporter type; the estimates for the margins are directly comparable, the regime group estimates are not in deviation of the base category. Fixed versus flexible exchange rate regimes (time-variant) are based on Ilzetzki et al. (2017), while the 'high exports' regime is determined by countries above the median of time-averaged exports/GDP (next to identical results if we use the annual data to categorise countries). Exporter type is exclusive (i.e. no change over time), 'Comm' indicates commodity exporters with diversified economies the alternative category. Absolute $t$-ratios in parentheses. ${ }^{*},{ }^{* *}$ and ${ }^{* * *}$ indicate statistical significance (difference from zero) at the $10 \%, 5 \%$ and $1 \%$ level, respectively. In this table we omit commodity price volatility, though results are qualitatively unchanged if we include this variable by export type. Column (1) is based on the preferred result in column (4) of Table 1 in the main text, columns (4) and (5) above have a marginally reduced sample (no data for CPV). 


\section{Appendix}

\section{A Data Sources and Sample Makeup}

Crisis Data Our data on banking crises identifying the start year of an event is taken from a 2017 update to Laeven and Valencia (2013) which covers banking crises up to 2015.

Commodity Price Data Variables related to aggregate commodity price growth and its volatility are constructed from IMF Primary Commodity Prices (monthly data) using (fixed) weights from Gruss (2014). Details of the weighting, data filtering and transformation are described in the main text of the paper.

Controls A substantial number of our control variables come from the World Bank World Development Indicators (WDI): Real GDP growth (in \%), Inflation (GDP deflator, in \%), M2/reserves (in $\%$ ), short-term debt (in \% of total external debt), size (broad money in \% of GDP), overseas development assistance (foreign aid) as a share of GNI, depreciation (growth rate of the annual LCU-US\$ exchange rate), total debt service (in \% of exports of goods, services and primary income), and trade openness (Merchandise trade in \% of GDP).

For domestic credit to the private sector we adopt the change of the domestic credit-to-GDP ratio (in $\%$ ), where credit/GDP is taken from WDI, integrated with FinStats and Global Financial Development Database (GFDD) series (both also from the World Bank). ${ }^{29}$

Public debt to GDP is taken from the IMF World Economic Outlook database.

Net capital inflows as a share of GDP is taken from the IMF Financial Flows Analytics (FFA) Database. More specifically this refers to the 'Total Net Nonofficial Inflows, in percent of GDP in U.S. Dollars.' The other variables used in a robustness check (FDI and non-FDI net flows) are taken/constructed from this dataset as well. The Herfindahl-Hirschman index for overseas development assistance (ODA) aid share by donor is based on OECD DAC data.

From the IMF International Financial Statistics we use lines 22d, 24, and 25: for liquidity we divide claims (22d) by demand deposits (24) and other deposits (25).

Conflict is taken from the UCDP/PRIO Armed Conflict Dataset (version 4-2016) which covers 19462015. We code countries as being in conflict if they have an intensity score of 2. The deposit insurance dummy (deposit guarantee scheme) is based on a July 2015 update of the 'Deposit Insurance Database' by Demirguc-Kunt et al. (2008). Fiscal crisis events are taken from the Gerling

\footnotetext{
${ }^{29}$ This variable is selected in Jordà et al. $(2011,2013,2015,2016)$ and Gourinchas and Obstfeld (2012) among others. We convinced ourselves that all results presented are qualitatively unchanged if we select real credit growth instead.
}

(i) 
et al. (2017) database, currency crises from the update of the Laeven and Valencia (2013) dataset (we construct crisis start year dummies in both cases).

The 10-year Treasury constant maturity date is taken from FRED. We select the year-end value on the final trading day of each year from this daily dataset.

Net foreign assets as a share of GDP, separating out FDI from non-FDI assets, are computed from assets and liabilities brought together in the updated External Wealth of Nations database (Lane and Milesi-Ferretti, 2007).

All of the above variable representing ratios or growth rates were transformed into percent values if not already in this format in the original data.

For the closer analysis of credit and capital inflows we create dummies for 'bonanzas' and 'surges' following the definitions in Caballero (2016) and Ghosh et al. (2014), respectively. Note that these indicators are constructed from the annual flow data and not the winsorized, MA-transformed data. Bonanzas are measured as periods of deviation from the long-run trend (HP-filtered) of credit volumes or capital inflows, where the threshold is taken as 1 or 2 standard deviations. ${ }^{30}$ Surges are defined as periods when an observation of capital flows or credit volume is both in the top 30th percentile of an individual country and in the top 30th percentile of the entire sample of 60 countries.

Sample Our sample is made up of 60 PRGT-eligible low-income economies with 1,550 observations the over 1981-2015 period. A total of 73 countries are eligible, but we were forced to drop 13 of these due to insufficient data on control variables - the countries dropped are primarily fragile states (including Afghanistan, Somalia and South Sudan) or small island states (including Micronesia, Kiribati and the Marshall Islands), with Vietnam the only notable larger economy omitted. None of the 13 countries dropped experienced a banking crisis in the 1981-2015 time period.

In our sample of 60 countries 29 economies experienced 35 banking crises. In Table A-2 below we indicate the sample make-up, indicating the eight crises we miss due to insufficient data on controls.

Levels versus growth rates or ratios A common practice in most of the empirical literature on EWS is to include macroeconomic variables in levels-primarily per capita GDP - to the crisis prediction model (see, among others, Aizenman and Noy, 2013; Beck et al., 2006). This practice is of concern when these macroeconomic variables display stochastic trends: the theoretical time series literature suggests that this data property leads to stark outcomes whereby the sample proportion of binary choices follows an arc sine law, meaning it is either close to zero or close to unity most of the time, implying either large numbers of repeated crises in individual countries alongside the virtual absence of crisis in all others (Park and Phillips, 2000). Since no country in our sample experienced

\footnotetext{
${ }^{30}$ In the credit bonanza results adopting a 2 sd threshold identifies only a single event and is therefore not analysed.
}

(ii)

C)International Monetary Fund. Not for Redistribution 
more than two banking crises over the post-WWII period, it would be difficult to argue that our data represent an empirical example of the stochastic process just described. Therefore, in our empirical application we focus on growth rates or ratios, which are less likely to be characterized by a stochastic trend.

(iii) 
Table A-1: Descriptive Statistics

\begin{tabular}{|c|c|c|c|c|c|}
\hline \multirow[b]{2}{*}{ Variable } & \multicolumn{5}{|c|}{ Full sample 1981-2015 } \\
\hline & mean & median & SD & Min & $\operatorname{Max}$ \\
\hline Banking Crisis dummy $\dagger$ & 0.023 & 0 & & 0 & 1 \\
\hline Aggregate Commodity Price Growth & 0.076 & 0.003 & 2.418 & -20.194 & 22.325 \\
\hline Price Growth Volatility & 0.305 & 0.020 & 1.086 & 0.001 & 16.090 \\
\hline Change in Credit/GDP (in \%) & -9.144 & -5.106 & 19.366 & -113.634 & 37.959 \\
\hline $\mathrm{M} 2 /$ Reserves (in \%) & 6.289 & 2.907 & 10.686 & 0.806 & 70.697 \\
\hline Public Debt/GDP (in \%) & 77.393 & 61.137 & 55.066 & 16.296 & 284.253 \\
\hline Inflation (in \%) & 11.640 & 7.902 & 13.384 & -3.887 & 84.504 \\
\hline Real GDP growth (in \%) & 3.872 & 3.976 & 3.095 & -6.580 & 14.074 \\
\hline Net Capital Inflows/GDP (in \%) & 3.274 & 2.099 & 4.878 & -7.651 & 20.489 \\
\hline Overseas Development Assistance/GNI (in \%) & 11.556 & 10.097 & 8.019 & 0.915 & 41.237 \\
\hline Trade Openness: (Exports + Imports)/GDP (in \%) & 55.856 & 49.671 & 26.725 & 15.894 & 124.744 \\
\hline Debt service (in $\%$ of total exports of goods and services) & 13.677 & 10.431 & 10.916 & 0.814 & 49.937 \\
\hline Short-term debt as a share of total external debt (in \%) & 21.075 & 16.149 & 15.318 & 2.893 & 61.756 \\
\hline Herfindahl-Hirschman Index of Aid Concentration & 0.825 & 0.854 & 0.097 & 0.460 & 0.926 \\
\hline Exchange Rate Depreciation (in \%) & 7.180 & 3.314 & 12.658 & -9.972 & 67.450 \\
\hline Liquidity (in \%) & 82.438 & 74.568 & 42.321 & 20.763 & 231.220 \\
\hline Size (in \%) & 34.704 & 27.562 & 21.142 & 9.907 & 94.461 \\
\hline Deposit insurance dummy & 0.139 & 0 & & 0 & 1 \\
\hline Currency crisis (start year) dummy & 0.034 & 0 & & 0 & 0.333 \\
\hline Fiscal crisis (start year) dummy & 0.094 & 0 & & 0 & 0.333 \\
\hline US Treasury rate & 6.019 & 5.547 & 2.827 & 2.237 & 12.257 \\
\hline Net foreign FDI assets/GDP (in \%) & -23.852 & -12.771 & 28.210 & -119.946 & 0 \\
\hline Net foreign non-FDI assets/GDP (in \%) & -44.375 & -31.909 & 51.813 & -206.331 & 41.967 \\
\hline Net FDI Inflows/GDP (in \%) & 3.124 & 1.712 & 3.678 & -0.539 & 16.469 \\
\hline Net non-FDI Inflows/GDP (in \%) & 0.133 & 0.132 & 2.965 & -10.530 & 9.902 \\
\hline Credit/GDP Bonanza (1sd) dummy & 0.005 & 0 & & 0 & 0.667 \\
\hline Credit/GDP Surge (at time $t$ ) dummy & 0.178 & 0 & & 0 & 1 \\
\hline Credit/GDP Surge (3 consec. periods) dummy & 0.177 & 0 & & 0 & 1 \\
\hline Net Capital Inflow/GDP Bonanza (1sd) dummy & 0.046 & 0 & & 0 & 0.667 \\
\hline Net Capital Inflow/GDP Bonanza (2sd) dummy & 0.005 & 0 & & 0 & 0.333 \\
\hline Net Capital Inflow/GDP Surge (at time $t$ ) dummy & 0.231 & 0 & & 0 & 1 \\
\hline Net Capital Inflow/GDP Surge (3 consec. periods) dummy & 0.187 & 0 & & 0 & 1 \\
\hline Net FDI Inflow/GDP Bonanza (1sd) dummy & 0.041 & 0 & & 0 & 0.667 \\
\hline Net FDI Inflow/GDP Bonanza (2sd) dummy & 0.010 & 0 & & 0 & 0.333 \\
\hline Net non-FDI Inflow/GDP Bonanza (1sd) dummy & 0.057 & 0 & & 0 & 0.667 \\
\hline Net non-FDI Inflow/GDP Bonanza (2sd) dummy & 0.010 & 0 & & 0 & 0.333 \\
\hline Net FDI Inflow/GDP Surge (at time $t$ ) dummy & 0.222 & 0 & & 0 & 1 \\
\hline Net FDI Inflow/GDP Surge (3 consec. periods) dummy & 0.186 & 0 & & 0 & 1 \\
\hline Net non-FDI Inflow/GDP Surge (at time $t$ ) dummy & 0.237 & 0 & & 0 & 1 \\
\hline Net non-FDI Inflow/GDP Surge (3 consec. periods) dummy & 0.162 & 0 & & 0 & 1 \\
\hline
\end{tabular}

Notes: We present descriptive statistics for $N=60$ countries, covering 35 crises in the time period 1981-2015. The full sample has $n=1,550$ observations. Dummy/indicator variables are marked with $D$. $\dagger$ All variables are transformed into $\mathrm{MA}(3)$ processes with the exception of the banking crisis start year dependent variable. This MA(3) transformation explains why some of the dummy variables have maximum values of 0.33 (equal to 1 in one of three consecutive years) or 0.67 (equal to 1 in two of three consecutive years).

(iv)

CInternational Monetary Fund. Not for Redistribution 
Table A-2: Regression Sample Makeup

\begin{tabular}{|c|c|c|c|c|c|c|c|c|c|c|c|}
\hline & \multirow[t]{2}{*}{ ISO } & \multirow[t]{2}{*}{ Name } & \multirow[t]{2}{*}{ obs } & \multirow[t]{2}{*}{ share $(\%)$} & \multicolumn{7}{|c|}{ Banking Crises } \\
\hline & & & & & all & year 1 & year 2 & sample & year 1 & year 2 & drop \\
\hline 1 & BDI & Burundi & 26 & 1.7 & 1 & 1994 & & 1 & 1994 & & \\
\hline 2 & BEN & Benin & 27 & 1.7 & 1 & 1988 & & 1 & 1988 & & \\
\hline 3 & BFA & Burkina Faso & 28 & 1.8 & 1 & 1990 & & 1 & 1990 & & \\
\hline 4 & BGD & Bangladesh & 35 & 2.3 & 1 & 1987 & & 1 & 1987 & & \\
\hline 5 & $\mathrm{BOL}$ & Bolivia & 35 & 2.3 & 2 & 1986 & 1994 & 2 & 1986 & 1994 & \\
\hline 6 & BTN $^{\dagger}$ & Bhutan & 9 & 0.6 & & & & & & & \\
\hline 7 & CAF & Central African Rep. & 16 & 1.0 & 1 & 1995 & & 1 & 1995 & & \\
\hline 8 & CIV & Cote d'Ivoire & 31 & 2.0 & 1 & 1988 & & 1 & 1988 & & \\
\hline 9 & CMR & Cameroon & 29 & 1.9 & 2 & 1987 & 1995 & 2 & 1987 & 1995 & \\
\hline 10 & COG & Congo, Republic & 28 & 1.8 & 1 & 1992 & & 1 & 1992 & & \\
\hline 11 & $\mathrm{COM}^{\dagger}$ & Comoros & 12 & 0.8 & & & & & & & \\
\hline 12 & CPV & Cape Verde & 34 & 2.2 & & & & & & & \\
\hline 13 & DJI & Djibouti & 13 & 0.8 & 1 & 1991 & & & & & 1 \\
\hline 14 & DMA & Dominica & 35 & 2.3 & & & & & & & \\
\hline 15 & $\mathrm{ERI}^{\dagger}$ & Eritrea & 7 & 0.5 & 1 & 1993 & & & & & 1 \\
\hline 16 & ETH & Ethiopia & 29 & 1.9 & & & & & & & \\
\hline 17 & GHA & Ghana & 34 & 2.2 & 1 & 1982 & & 1 & 1982 & & \\
\hline 18 & GIN & Guinea & 20 & 1.3 & 2 & 1985 & 1993 & 1 & & 1993 & 1 \\
\hline 19 & GMB & The Gambia & 32 & 2.1 & & & & & & & \\
\hline 20 & GNB & Guinea-Bissau & 21 & 1.4 & 1 & 1995 & & 1 & 1995 & & \\
\hline 21 & GRD & Grenada & 35 & 2.3 & & & & & & & \\
\hline 22 & GUY & Guyana & 31 & 2.0 & 1 & 1993 & & 1 & 1993 & & \\
\hline 23 & HND & Honduras & 35 & 2.3 & & & & & & & \\
\hline 24 & $\mathrm{HTI}$ & Haiti & 17 & 1.1 & 1 & 1994 & & & & & 1 \\
\hline 25 & KEN & Kenya & 33 & 2.1 & 2 & 1985 & 1992 & 2 & 1985 & 1992 & \\
\hline 26 & KGZ & Kyrgyz Republic & 16 & 1.0 & 1 & 1995 & & & & & 1 \\
\hline 27 & KHM & Cambodia & 19 & 1.2 & & & & & & & \\
\hline 28 & LAO & Lao PDR & 23 & 1.5 & & & & & & & \\
\hline 29 & LCA & St. Lucia & 34 & 2.2 & & & & & & & \\
\hline 30 & LSO & Lesotho & 35 & 2.3 & & & & & & & \\
\hline 31 & MDA & Moldova & 18 & 1.2 & 1 & 2014 & & 1 & 2014 & & \\
\hline 32 & MDG & Madagascar & 35 & 2.3 & 1 & 1988 & & 1 & 1988 & & \\
\hline 33 & $\mathrm{MDV}^{\dagger}$ & Maldives & 13 & 0.8 & & & & & & & \\
\hline 34 & MLI & Mali & 31 & 2.0 & 1 & 1987 & & 1 & 1987 & & \\
\hline 35 & $\mathrm{MMR}^{\dagger}$ & Myanmar & 15 & 1.0 & & & & & & & \\
\hline 36 & MNG & Mongolia & 20 & 1.3 & 1 & 2008 & & 1 & 2008 & & \\
\hline 37 & $\mathrm{MOZ}$ & Mozambique & 16 & 1.0 & 1 & 1987 & & & & & 1 \\
\hline 38 & MRT & Mauritania & 17 & 1.1 & 1 & 1984 & & 1 & 1984 & & \\
\hline 39 & MWI & Malawi & 35 & 2.3 & & & & & & & \\
\hline 40 & NER & Niger & 33 & 2.1 & 1 & 1983 & & 1 & 1983 & & \\
\hline 41 & NGA & Nigeria & 29 & 1.9 & 2 & 1991 & 2009 & 2 & 1991 & 2009 & \\
\hline 42 & $\mathrm{NIC}$ & Nicaragua & 30 & 1.9 & 2 & 1990 & 2000 & 2 & 1990 & 2000 & \\
\hline 43 & NPL & Nepal & 35 & 2.3 & 1 & 1988 & & 1 & 1988 & & \\
\hline 44 & PNG & Papua New Guinea & 35 & 2.3 & & & & & & & \\
\hline 45 & RWA & Rwanda & 28 & 1.8 & & & & & & & \\
\hline 46 & SDN & Sudan & 23 & 1.5 & & & & & & & \\
\hline 47 & SEN & Senegal & 32 & 2.1 & 1 & 1988 & & 1 & 1988 & & \\
\hline 48 & SLB & Solomon Islands & 24 & 1.6 & & & & & & & \\
\hline 49 & SLE & Sierra Leone & 31 & 2.0 & 1 & 1990 & & 1 & 1990 & & \\
\hline 50 & $\mathrm{STP}^{\dagger}$ & São Tomé \& Principle & 13 & 0.8 & & & & & & & \\
\hline 51 & $\mathrm{TCD}^{\dagger}$ & Chad & 13 & 0.8 & 2 & 1983 & 1992 & 2 & 1983 & 1992 & \\
\hline 52 & TGO & Togo & 34 & 2.2 & 1 & 1993 & & 1 & 1993 & & \\
\hline 53 & $\mathrm{TJK}^{\dagger}$ & Tajikistan & 13 & 0.8 & & & & & & & \\
\hline 54 & TON & Tonga & 21 & 1.4 & & & & & & & \\
\hline 55 & TZA & Tanzania & 26 & 1.7 & 1 & 1987 & & & & & 1 \\
\hline 56 & UGA & Uganda & 29 & 1.9 & 1 & 1994 & & 1 & 1994 & & \\
\hline 57 & VCT & St. Vincent \& Grenadines & 35 & 2.3 & & & & & & & \\
\hline 58 & VUT & Vanuatu & 33 & 2.1 & & & & & & & \\
\hline 59 & YEM & Yemen, Republic of & 23 & 1.5 & 1 & 1996 & & 1 & 1996 & & \\
\hline 60 & ZMB & Zambia & 31 & 2.0 & 1 & 1995 & & & & & 1 \\
\hline
\end{tabular}

Notes: 'All' indicates the number of crises from Laeven and Valencia (2017), 'sample' which make it into our regression sample. 'Drop' indicates the number of crises we miss out on due to lack of data on controls. The sample amounts to 1,550 observations in 60 Countries over 1981-2015; those marked with $\dagger$ are dropped in the robustness checks in columns (a) and (c) of Table 2 of the main text (15 observations or fewer).

(v)

CInternational Monetary Fund. Not for Redistribution 


\section{B Additional Figures}

Figure B-1: Private Credit in LICs

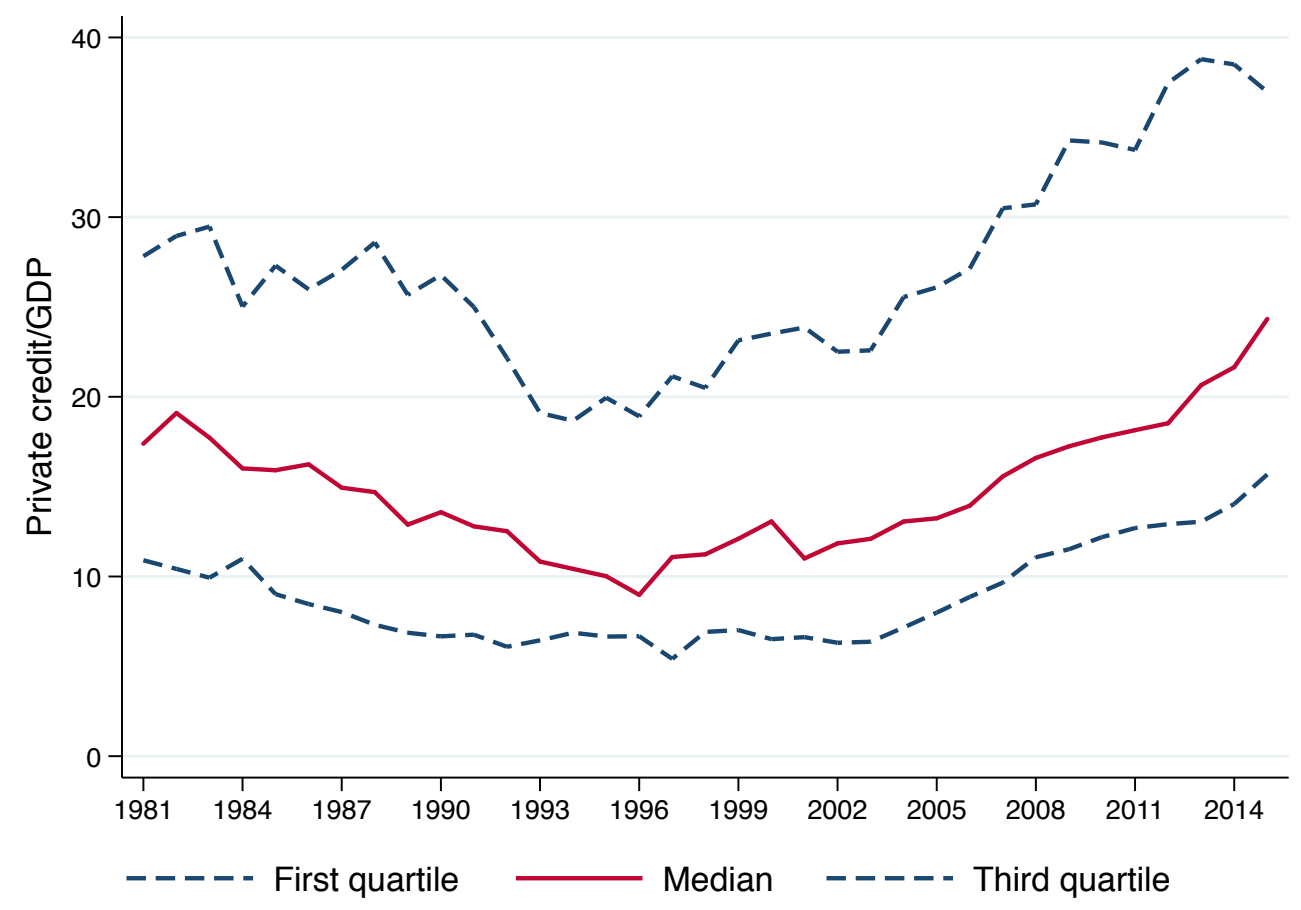

Notes: $N=60$ PRGT-eligible economies.

Figure B-2: Net Private Capital Inflows in LICs

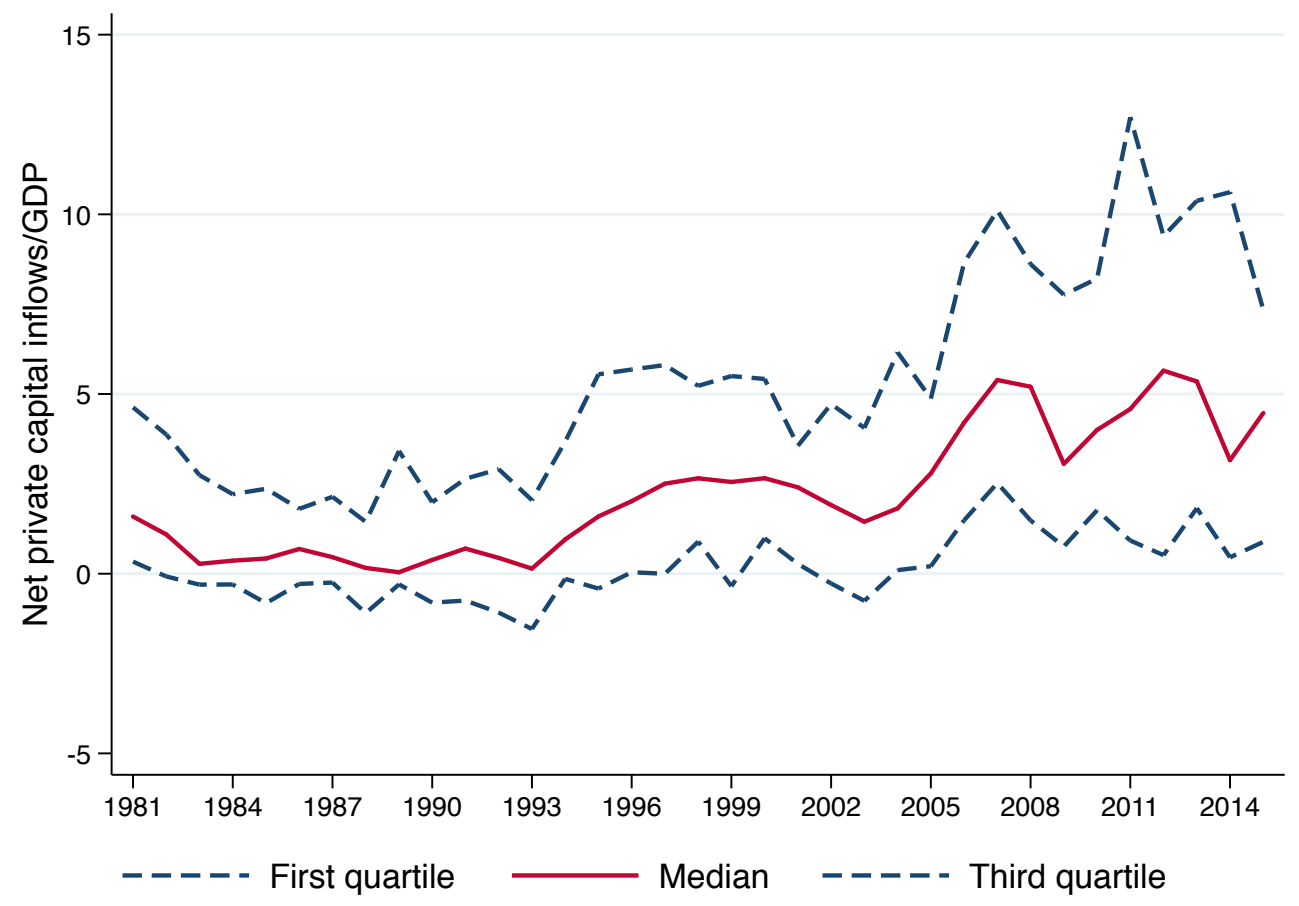

Notes: $N=60$ PRGT-eligible economies.

(vi)

CInternational Monetary Fund. Not for Redistribution 
Figure B-3: Banking and Currency Crises in LICs

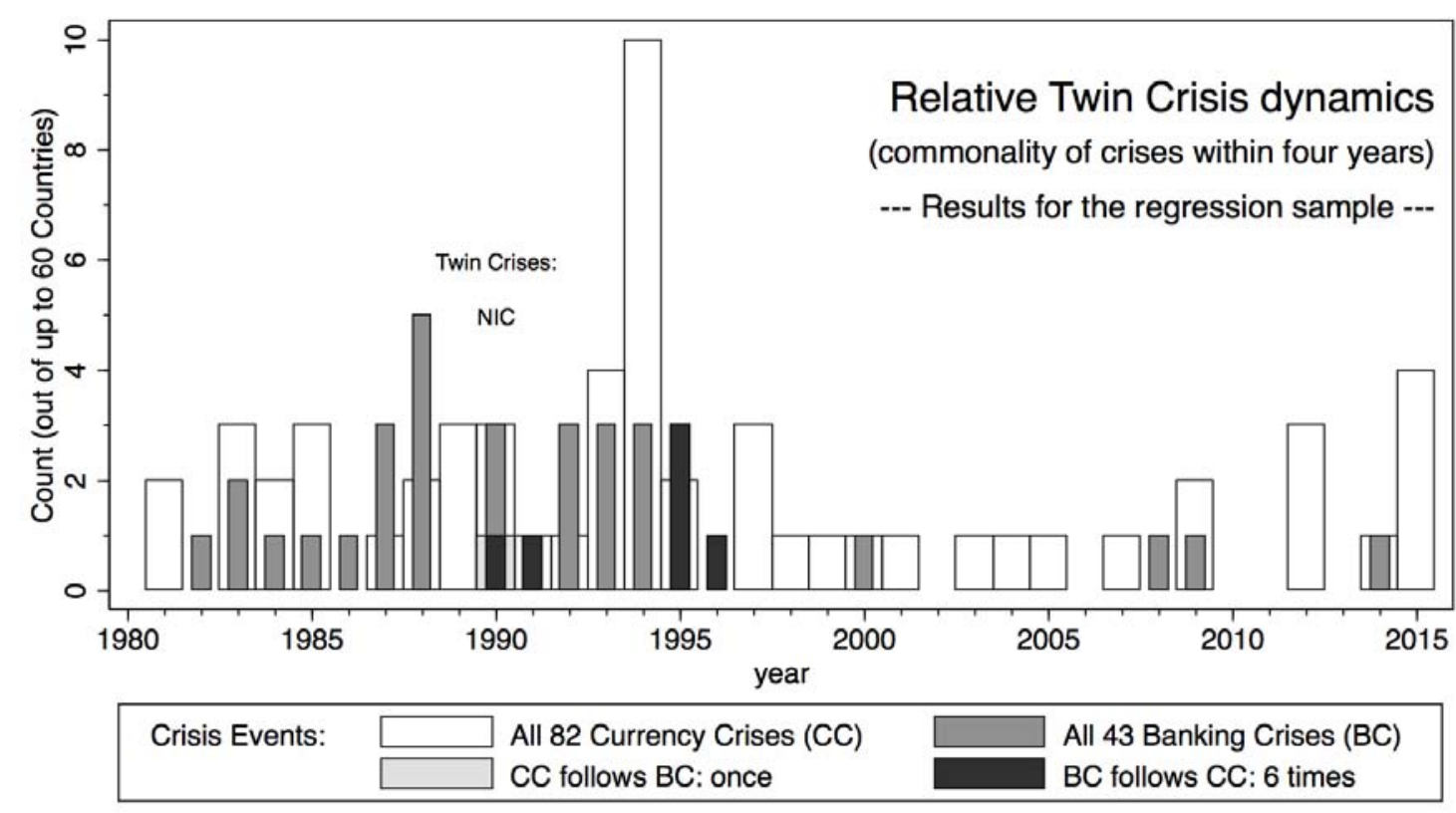

Notes: $N=60$ PRGT-eligible economies.

Figure B-4: Banking and Fiscal Crises in LICs

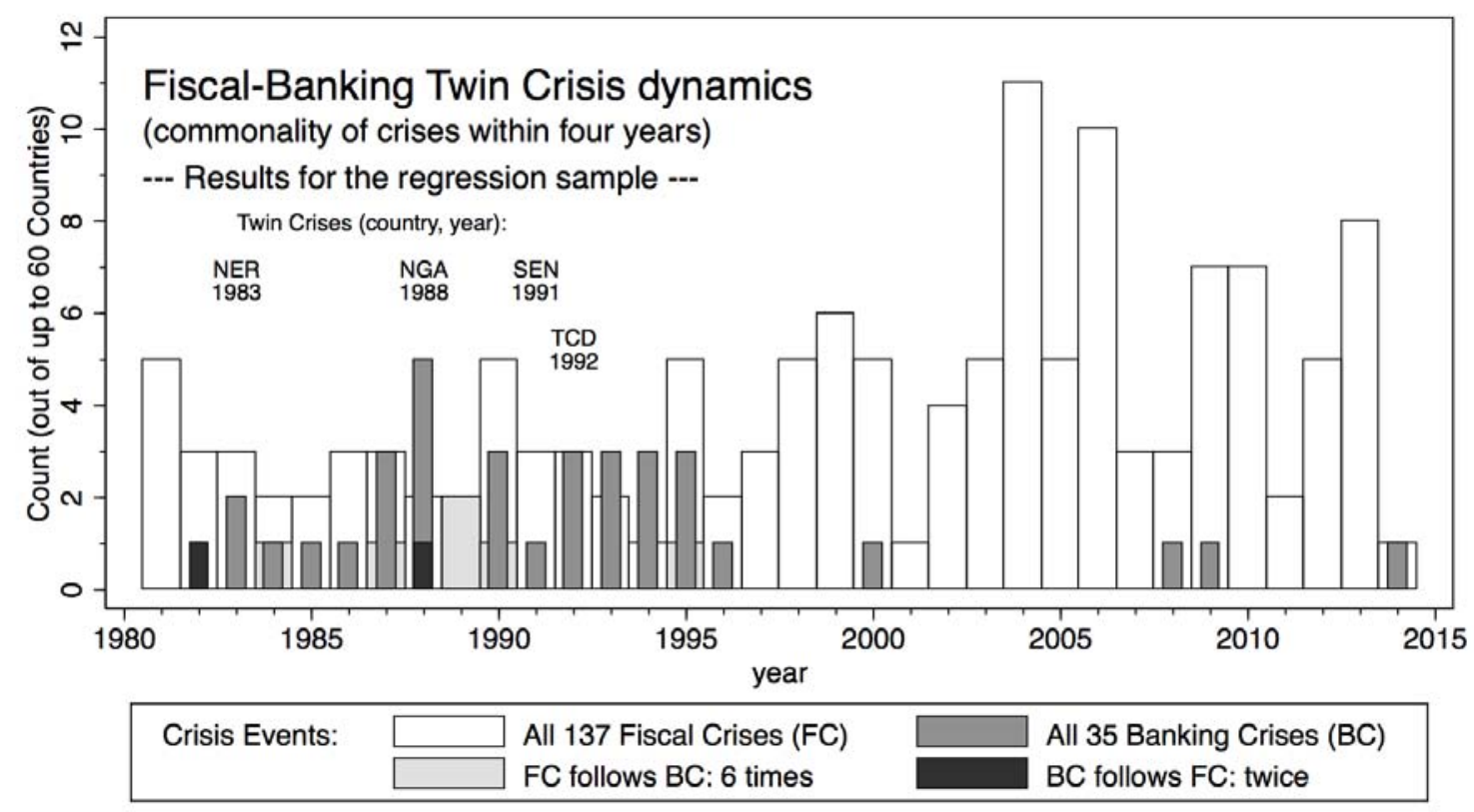

Notes: $N=60$ PRGT-eligible economies.

(vii)

CInternational Monetary Fund. Not for Redistribution 


\section{Additional Regression Results}

Table B-1: Main Results - Full Results (Economic Magnitudes)

\begin{tabular}{|c|c|c|c|c|c|c|}
\hline \multirow[b]{2}{*}{ DV: Crisis Start Year } & \multicolumn{4}{|c|}{ RE-Mundlak Logit } & \multirow{2}{*}{$\begin{array}{l}\text { Logit } \\
(5)\end{array}$} & \multirow{2}{*}{$\begin{array}{c}\text { Logit FE } \\
\text { (6) }\end{array}$} \\
\hline & $(1)$ & $(2)$ & (3) & $(4)$ & & \\
\hline \multicolumn{7}{|c|}{ Selected Covariates (in percent, winsorized, MA(3)) } \\
\hline Commodity Price Growth & $\begin{array}{r}-0.622 \\
(3.05)^{* * *}\end{array}$ & $\begin{array}{r}-1.046 \\
(3.30)^{* * *}\end{array}$ & $\begin{array}{r}-0.836 \\
(2.53) * *\end{array}$ & $\begin{array}{r}-1.381 \\
(2.28)^{* *}\end{array}$ & $\begin{array}{r}-1.026 \\
(2.82)^{* * *}\end{array}$ & $\begin{array}{r}-6.859 \\
(0.41)\end{array}$ \\
\hline $\begin{array}{l}\text { Commodity Price } \\
\text { Growth Volatility }\end{array}$ & $\begin{array}{r}1.964 \\
(2.37)^{* *}\end{array}$ & $\begin{array}{r}1.463 \\
(2.68)^{* * *}\end{array}$ & $\begin{array}{r}1.577 \\
(1.46)\end{array}$ & $\begin{array}{r}0.710 \\
(0.37)\end{array}$ & $\begin{array}{r}-0.624 \\
(1.32)\end{array}$ & $\begin{array}{r}1.734 \\
(0.06)\end{array}$ \\
\hline Liquidity & & $\begin{array}{r}-0.102 \\
(0.18)\end{array}$ & $\begin{array}{l}-0.317 \\
(0.59)\end{array}$ & $\begin{array}{r}-0.652 \\
(1.10)\end{array}$ & $\begin{array}{r}0.592 \\
(2.11)^{* *}\end{array}$ & $\begin{array}{r}-3.523 \\
(0.70)\end{array}$ \\
\hline Size & & $\begin{array}{r}0.457 \\
(0.49)\end{array}$ & $\begin{array}{r}-0.070 \\
(0.08)\end{array}$ & $\begin{array}{r}0.844 \\
(1.02)\end{array}$ & $\begin{array}{r}-0.440 \\
(1.12)\end{array}$ & $\begin{array}{r}3.714 \\
(0.57)\end{array}$ \\
\hline Credit/GDP Growth & & & $\begin{array}{r}0.699 \\
(0.83)\end{array}$ & $\begin{array}{r}1.001 \\
(1.01)\end{array}$ & $\begin{array}{r}0.343 \\
(0.52)\end{array}$ & $\begin{array}{r}6.627 \\
(1.08)\end{array}$ \\
\hline M2/Reserves & & & $\begin{array}{r}1.049 \\
(2.47)^{* *}\end{array}$ & $\begin{array}{r}1.124 \\
(2.63)^{* * *}\end{array}$ & $\begin{array}{r}0.536 \\
(2.32)^{* *}\end{array}$ & $\begin{array}{r}8.568 \\
(1.21)\end{array}$ \\
\hline Public Debt/GDP & & & $\begin{array}{r}0.688 \\
(1.19)\end{array}$ & $\begin{array}{r}0.116 \\
(0.19)\end{array}$ & $\begin{array}{r}0.088 \\
(0.25)\end{array}$ & $\begin{array}{r}3.361 \\
(0.54)\end{array}$ \\
\hline Real GDP growth & & & $\begin{array}{r}0.638 \\
(1.18)\end{array}$ & $\begin{array}{r}0.445 \\
(0.83)\end{array}$ & $\begin{array}{l}-0.087 \\
(0.22)\end{array}$ & $\begin{array}{r}1.702 \\
(0.57)\end{array}$ \\
\hline Inflation & & & $\begin{array}{r}1.182 \\
(1.62)\end{array}$ & $\begin{array}{r}1.498 \\
(1.71)^{*}\end{array}$ & $\begin{array}{r}0.766 \\
(1.36)\end{array}$ & $\begin{array}{r}9.900 \\
(1.47)\end{array}$ \\
\hline Net Capital Inflows/GDP & & & & $\begin{array}{r}0.992 \\
(2.30)^{* *}\end{array}$ & $\begin{array}{r}0.347 \\
(0.71)\end{array}$ & $\begin{array}{r}5.944 \\
(1.16)\end{array}$ \\
\hline Official development assistance/GNI & & & & $\begin{array}{r}2.122 \\
(3.25)^{* * *}\end{array}$ & $\begin{array}{r}0.441 \\
(1.22)\end{array}$ & $\begin{array}{r}10.336 \\
(1.65)^{*}\end{array}$ \\
\hline Trade Openness & & & & $\begin{array}{r}-2.592 \\
(2.60)^{* * *}\end{array}$ & $\begin{array}{r}-0.823 \\
(1.84)^{*}\end{array}$ & $\begin{array}{r}-14.702 \\
(0.93)\end{array}$ \\
\hline 10-yr US Treasury Rate eoy & $\begin{array}{r}1.318 \\
(3.84)^{* * *}\end{array}$ & $\begin{array}{r}1.596 \\
(3.45)^{* * *}\end{array}$ & $\begin{array}{r}1.463 \\
(2.95)^{* * *}\end{array}$ & $\begin{array}{r}1.872 \\
(3.70)^{* * *}\end{array}$ & $\begin{array}{r}1.026 \\
(2.75)^{* * *}\end{array}$ & $\begin{array}{r}9.785 \\
(2.03) * *\end{array}$ \\
\hline \multicolumn{7}{|c|}{ Additional Covariate Groups (Dummies) } \\
\hline Deposit Insurance Dummy & $x$ & $\times$ & $\times$ & $\times$ & $\times$ & $x$ \\
\hline Crisis Dummies & $\times$ & $\times$ & $\times$ & $\times$ & $\times$ & $x$ \\
\hline Observations & 1,550 & 1,550 & 1,550 & 1,550 & 1,550 & 804 \\
\hline Countries & 60 & 60 & 60 & 60 & 60 & 29 \\
\hline Crises & 35 & 35 & 35 & 35 & 35 & 35 \\
\hline $\log L$ & -148.20 & -143.38 & -135.21 & -127.15 & -141.40 & -84.05 \\
\hline AUROC & 0.799 & 0.822 & 0.858 & 0.882 & 0.829 & 0.748 \\
\hline seAUROC & 0.028 & 0.026 & 0.025 & 0.024 & 0.030 & 0.041 \\
\hline ROC Comparison & & (2) vs (1) & (3) vs (1) & (4) vs (3) & (4) vs (5) & (4) vs (6) \\
\hline ROC Comp $p$-value & & 0.230 & 0.008 & 0.103 & 0.007 & 0.024 \\
\hline Wald $\chi^{2}(\mathrm{FE})$ & 13.55 & 16.05 & 42.66 & 72.98 & & \\
\hline Wald $p$-value & 0.035 & 0.042 & 0.000 & 0.000 & & \\
\hline
\end{tabular}

Notes: The estimates presented are marginal effects multiplied by the covariate standard deviation - the computation of marginal effects prevents us from presenting results for three dummy variables (deposit insurance [+ve significant in (4) only], currency crisis [insignficant throughout], and fiscal crisis [-ve significant throughout, except in (6)]). ${ }^{*}, * *$ and ${ }^{* * *}$ indicate statistical significance at the $10 \%, 5 \%$ and $1 \%$ level, respectively. See Table 1 in the main text for all other details.

(viii)

CInternational Monetary Fund. Not for Redistribution 
Table B-2: Additional Controls - Economic Magnitudes

\begin{tabular}{|c|c|c|c|c|c|c|c|c|c|c|}
\hline \multirow[b]{2}{*}{ DV: Crisis Start Year } & \multicolumn{10}{|c|}{ RE-Mundlak Logit } \\
\hline & (1) & (2) & (3) & (4) & (5) & (6) & (7) & (8) & (9) & (10) \\
\hline Commodity price growth & $\begin{array}{r}-1.381 \\
(2.28)^{* *}\end{array}$ & $\begin{array}{r}-1.481 \\
(2.45)^{* *}\end{array}$ & $\begin{array}{r}-1.578 \\
(2.28)^{* *}\end{array}$ & $\begin{array}{r}-1.531 \\
(2.25)^{* *}\end{array}$ & $\begin{array}{r}-1.534 \\
(2.28)^{* *}\end{array}$ & $\begin{array}{r}-1.383 \\
(2.32)^{* *}\end{array}$ & $\begin{array}{c}-1.363 \\
(2.17)^{* *}\end{array}$ & $\begin{array}{c}-1.312 \\
(2.18)^{* *}\end{array}$ & $\begin{array}{r}-1.382 \\
(2.44)^{* *}\end{array}$ & $\begin{array}{r}-1.440 \\
(2.39)^{* *}\end{array}$ \\
\hline Commodity Price Volatility & $\begin{array}{r}0.710 \\
(0.37)\end{array}$ & $\begin{array}{c}0.803 \\
(0.40)\end{array}$ & $\begin{array}{c}-0.165 \\
(0.08)\end{array}$ & $\begin{array}{r}0.514 \\
(0.28)\end{array}$ & $\begin{array}{r}0.093 \\
(0.04)\end{array}$ & $\begin{array}{c}0.708 \\
(0.36)\end{array}$ & $\begin{array}{r}0.570 \\
(0.31)\end{array}$ & $\begin{array}{c}0.707 \\
(0.36)\end{array}$ & $\begin{array}{l}1.134 \\
(0.58)\end{array}$ & $\begin{array}{l}0.622 \\
(0.31)\end{array}$ \\
\hline Credit/GDP Growth & $\begin{array}{c}1.001 \\
(1.01)\end{array}$ & $\begin{array}{r}1.176 \\
(1.15)\end{array}$ & $\begin{array}{c}1.191 \\
(1.15)\end{array}$ & $\begin{array}{c}1.152 \\
(1.14)\end{array}$ & $\begin{array}{c}1.191 \\
(1.16)\end{array}$ & $\begin{array}{c}0.993 \\
(0.99)\end{array}$ & $\begin{array}{c}1.052 \\
(1.04)\end{array}$ & $\begin{array}{c}1.032 \\
(1.04)\end{array}$ & $\begin{array}{c}1.123 \\
(1.10)\end{array}$ & $\begin{array}{l}1.059 \\
(1.08)\end{array}$ \\
\hline Global Credit/GDP Growth & & $\begin{array}{r}-1.172 \\
(2.09)^{* *}\end{array}$ & & & $\begin{array}{c}-0.812 \\
(1.19)\end{array}$ & & & & & \\
\hline Net Capital Inflows/GDP & $\begin{array}{r}0.992 \\
(2.30)^{* *}\end{array}$ & $\begin{array}{r}1.159 \\
(2.58)^{* *}\end{array}$ & $\begin{array}{r}1.249 \\
(2.73)^{* * *}\end{array}$ & $\begin{array}{r}1.159 \\
(2.58)^{* *}\end{array}$ & $\begin{array}{r}1.257 \\
(2.45)^{* *}\end{array}$ & $\begin{array}{r}1.003 \\
(2.29)^{* *}\end{array}$ & $\begin{array}{c}1.111 \\
(2.53)^{* *}\end{array}$ & $\begin{array}{r}0.990 \\
(2.17)^{* *}\end{array}$ & $\begin{array}{r}0.871 \\
(1.90)^{*}\end{array}$ & $\begin{array}{r}0.856 \\
(1.72)^{*}\end{array}$ \\
\hline Global Net Capital Inflows/GDP & & & $\begin{array}{c}-1.741 \\
(1.77)^{*}\end{array}$ & & $\begin{array}{l}-1.401 \\
(1.35)\end{array}$ & & & & & \\
\hline Public Debt/GDP & $\begin{array}{c}0.116 \\
(0.19)\end{array}$ & $\begin{array}{c}-0.237 \\
(0.35)\end{array}$ & $\begin{array}{l}-0.523 \\
(0.68)\end{array}$ & $\begin{array}{l}-0.419 \\
(0.52)\end{array}$ & $\begin{array}{c}-0.424 \\
(0.54)\end{array}$ & $\begin{array}{r}0.127 \\
(0.22)\end{array}$ & $\begin{array}{c}0.066 \\
(0.11)\end{array}$ & $\begin{array}{c}-0.138 \\
(0.26)\end{array}$ & $\begin{array}{c}0.286 \\
(0.46)\end{array}$ & $\begin{array}{l}0.044 \\
(0.08)\end{array}$ \\
\hline Global Public Debt/GDP & & & & $\begin{array}{r}1.041 \\
(1.35)\end{array}$ & $\begin{array}{c}-0.421 \\
(0.42)\end{array}$ & & & & & \\
\hline Depreciation & & & & & & $\begin{array}{c}-0.123 \\
(0.20)\end{array}$ & & & & \\
\hline $\mathrm{HH}$ index for ODA & & & & & & & $\begin{array}{c}0.358 \\
(0.47)\end{array}$ & & & \\
\hline Debt service/exports & & & & & & & & $\begin{array}{c}0.695 \\
(1.14)\end{array}$ & & \\
\hline Short-term/total ext. debt & & & & & & & & & $\begin{array}{r}2.065 \\
(1.42)\end{array}$ & \\
\hline Conflict & & & & & & & & & & $\begin{array}{l}-0.541 \\
(1.24)\end{array}$ \\
\hline Additional Covariates & $x$ & $x$ & $x$ & $x$ & $x$ & $x$ & $x$ & $x$ & $x$ & $x$ \\
\hline LogL & -127.15 & -124.67 & -124.47 & -125.99 & -123.67 & -127.12 & -126.31 & -126.43 & -126.14 & -126.42 \\
\hline AUROC & 0.882 & 0.889 & 0.885 & 0.884 & 0.888 & 0.882 & 0.884 & 0.884 & 0.887 & 0.885 \\
\hline se(AUROC) & 0.024 & 0.025 & 0.026 & 0.025 & 0.025 & 0.023 & 0.024 & 0.024 & 0.023 & 0.023 \\
\hline ROC Comp Model (1) $p$-value & & 0.404 & 0.766 & 0.670 & 0.551 & 0.786 & 0.496 & 0.634 & 0.136 & 0.278 \\
\hline
\end{tabular}

Notes: We present marginal effects (1sd increase in covariate) for alternative specifications to the results from column (4), Table 1 in the main text. The 'global' variables represent cross-section averages for the full sample (not including country $i$ ). Additional covariates are: GDP growth, inflation, M2/reserves, liquidity, size, ODA/GNI, trade openness, 10-yr US Treasury Rate and dummies for deposit insurance, currency crises and fiscal crises. Absolute $t$-ratios in parentheses. ${ }^{*},{ }^{* *}$ and ${ }^{* * *}$ indicate statistical significance at the $10 \%, 5 \%$ and $1 \%$ level, respectively. Wald tests confirm the statistical significance of the 'fixed effects' in all models. Sample: 35 crises in $N=60$ countries $(n=1,550)$. 
Table B-3: Main Results using base year commodity net exports/GDP as weights - Economic Magnitudes

\begin{tabular}{|c|c|c|c|c|c|c|}
\hline \multirow[b]{2}{*}{$\begin{array}{l}\text { Unconditional Crisis Probability } \\
\text { DV: Crisis Start Year }\end{array}$} & \multicolumn{4}{|c|}{ RE-Mundlak Logit } & \multirow{2}{*}{$\begin{array}{l}\text { Logit } \\
2.2 \% \\
(5)\end{array}$} & \multirow{2}{*}{$\begin{array}{r}\text { Logit FE } \\
4.3 \% \\
(6)\end{array}$} \\
\hline & $\begin{array}{r}2.2 \% \\
(1)\end{array}$ & $\begin{array}{r}2.2 \% \\
(2)\end{array}$ & $\begin{array}{r}2.2 \% \\
(3)\end{array}$ & $\begin{array}{r}2.2 \% \\
(4)\end{array}$ & & \\
\hline \multicolumn{7}{|c|}{ Selected Covariates (in percent, winsorized, MA(3)) } \\
\hline Commodity Price Growth & $\begin{array}{r}-0.880 \\
(3.70)^{* * *}\end{array}$ & $\begin{array}{r}-1.123 \\
(4.03)^{* * *}\end{array}$ & $\begin{array}{r}-0.835 \\
(2.85)^{* * *}\end{array}$ & $\begin{array}{r}-1.475 \\
(2.94)^{* * *}\end{array}$ & $\begin{array}{r}-0.944 \\
(2.98)^{* * *}\end{array}$ & $\begin{array}{r}-7.985 \\
(0.52)\end{array}$ \\
\hline $\begin{array}{l}\text { Commodity Price } \\
\text { Growth Volatility }\end{array}$ & $\begin{array}{r}3.040 \\
(0.67)\end{array}$ & $\begin{array}{r}3.071 \\
(0.68)\end{array}$ & $\begin{array}{l}3.118 \\
(0.81)\end{array}$ & $\begin{array}{r}2.524 \\
(0.65)\end{array}$ & $\begin{array}{l}-0.507 \\
(0.89)\end{array}$ & $\begin{array}{r}8.659 \\
(0.28)\end{array}$ \\
\hline Change in Credit/GDP & & & $\begin{array}{r}0.676 \\
(0.84)\end{array}$ & $\begin{array}{r}1.024 \\
(1.05)\end{array}$ & $\begin{array}{r}0.382 \\
(0.58)\end{array}$ & $\begin{array}{r}6.339 \\
(1.01)\end{array}$ \\
\hline M2/Reserves & & & $\begin{array}{r}1.041 \\
(2.41)^{* *}\end{array}$ & $\begin{array}{r}1.120 \\
(2.65)^{* * *}\end{array}$ & $\begin{array}{r}0.528 \\
(2.29)^{* *}\end{array}$ & $\begin{array}{r}8.039 \\
(1.13)\end{array}$ \\
\hline Public Debt/GDP & & & $\begin{array}{r}0.760 \\
(1.27)\end{array}$ & $\begin{array}{r}0.132 \\
(0.23)\end{array}$ & $\begin{array}{r}0.127 \\
(0.37)\end{array}$ & $\begin{array}{r}3.627 \\
(0.62)\end{array}$ \\
\hline Inflation & & & $\begin{array}{r}1.151 \\
(1.76)^{*}\end{array}$ & $\begin{array}{r}1.504 \\
(1.77)^{*}\end{array}$ & $\begin{array}{r}0.775 \\
(1.38)\end{array}$ & $\begin{array}{r}9.187 \\
(1.29)\end{array}$ \\
\hline Net Capital Inflows/GDP & & & & $\begin{array}{r}1.011 \\
(2.33)^{* *}\end{array}$ & $\begin{array}{r}0.335 \\
(0.71)\end{array}$ & $\begin{array}{r}5.674 \\
(1.06)\end{array}$ \\
\hline Foreign Aid/GNI & & & & $\begin{array}{r}2.106 \\
(3.29)^{* * *}\end{array}$ & $\begin{array}{r}0.426 \\
(1.16)\end{array}$ & $\begin{array}{r}9.787 \\
(1.38)\end{array}$ \\
\hline Trade Openness & & & & $\begin{array}{r}-2.274 \\
(2.33)^{* *} \\
\end{array}$ & $\begin{array}{r}-0.807 \\
(1.78)^{*}\end{array}$ & $\begin{array}{r}-14.066 \\
(0.88)\end{array}$ \\
\hline \multicolumn{7}{|l|}{ Effect Size } \\
\hline Commodity Price Growth & -0.39 & -0.50 & -0.37 & -0.65 & -0.42 & -1.83 \\
\hline Volatility & 1.35 & 1.36 & 1.38 & 1.12 & -0.22 & 1.99 \\
\hline Change in Credit/GDP & & & 0.30 & 0.45 & 0.17 & 1.46 \\
\hline M2/Reserves & & & 0.46 & 0.50 & 0.23 & 1.85 \\
\hline Public Debt/GDP & & & 0.34 & 0.06 & 0.06 & 0.83 \\
\hline Inflation & & & 0.51 & 0.67 & 0.34 & 2.11 \\
\hline Net Capital Inflows/GDP & & & & 0.45 & 0.15 & 1.30 \\
\hline Foreign Aid/GNI & & & & 0.93 & 0.19 & 2.25 \\
\hline Trade Openness & & & & -1.01 & -0.36 & -3.23 \\
\hline \multicolumn{7}{|l|}{ Additional Covariate Groups } \\
\hline Deposit Insurance \& Crisis Dummies & $x$ & $x$ & $x$ & $x$ & $x$ & $x$ \\
\hline 10-yr US Treasury Rate eoy & $x$ & $x$ & $\times$ & $x$ & $x$ & $\times$ \\
\hline Banking System & & $\times$ & $\times$ & $x$ & $\times$ & $x$ \\
\hline Macro Fundamentals & & & $\times$ & $\times$ & $\times$ & $\times$ \\
\hline $\log L$ & -148.05 & -144.31 & -135.57 & -127.65 & -141.33 & -83.72 \\
\hline AUROC & 0.799 & 0.820 & 0.855 & 0.881 & 0.831 & 0.730 \\
\hline se(AUROC) & 0.028 & 0.025 & 0.025 & 0.024 & 0.030 & 0.041 \\
\hline ROC Comparison & & (2) vs (1) & (3) vs (1) & (4) vs (3) & (5) vs (4) & (6) vs (4) \\
\hline ROC Comp $p$-value & & 0.209 & 0.011 & 0.080 & 0.009 & 0.005 \\
\hline Wald $\chi^{2}(\mathrm{FE})$ & 7.22 & 7.10 & 32.85 & 68.85 & & \\
\hline Wald $p$-value & 0.301 & 0.526 & 0.002 & 0.000 & & \\
\hline
\end{tabular}

Notes: The results in this table are derived from commodity price growth and volatility variables constructed from country-specific weights based on base year (1981) commodity net exports/GDP (instead of mean net exports/GDP in Table 1 of the main text). Sample of 35 banking crises in 60 (column (7): 29) countries, with 1,550 (804) observations. All results here are the economic magnitudes for a one standard deviation increase in the explanatory variable, expressed in percent. The 'Effect Size' section reports the associated effect of a 1sd increase in the covariate relative to the unconditional propensity of a crisis $(2.2 \%$ and $4.3 \%$ for the full and Logit FE samples, respectively) - this is helpful to compare results in the RE-Mundlak Logit and Pooled Logit models on the one hand and the Logit FE model on the other (with vastly differing unconditional crisis propensity). $\ddagger$ Due to the parsimony of the estimation equation we could not obtain standard errors for the marginal effects of these models via the Delta method. 
Table B-4: Main Results using mean commodity exports/GDP as weights - Economic Magnitudes

\begin{tabular}{|c|c|c|c|c|c|c|}
\hline \multirow[b]{2}{*}{$\begin{array}{l}\text { Unconditional Crisis Probability } \\
\text { Dep.Var.: Crisis Start Year }\end{array}$} & \multicolumn{4}{|c|}{ RE-Mundlak Logit } & \multirow{2}{*}{$\begin{array}{l}\text { Logit } \\
2.2 \% \\
(5)\end{array}$} & \multirow{2}{*}{$\begin{array}{r}\text { Logit FE } \\
4.3 \% \\
(6)\end{array}$} \\
\hline & $\begin{array}{r}2.2 \% \\
(1)\end{array}$ & $\begin{array}{r}2.2 \% \\
(2)\end{array}$ & $\begin{array}{r}2.2 \% \\
(3)\end{array}$ & $\begin{array}{r}2.2 \% \\
(4)\end{array}$ & & \\
\hline \multicolumn{7}{|c|}{ Selected Covariates (in percent, winsorized, MA(3)) } \\
\hline Commodity Price Growth & $\begin{array}{r}-0.610 \\
(2.83)^{* * *}\end{array}$ & $\begin{array}{r}-0.989 \\
(3.30)^{* * *}\end{array}$ & $\begin{array}{r}-0.797 \\
(2.52)^{* *}\end{array}$ & $\begin{array}{r}-0.999 \\
(2.56)^{* *}\end{array}$ & $\begin{array}{r}-0.879 \\
(2.64)^{* * *}\end{array}$ & $\begin{array}{l}-3.934 \\
(0.35)\end{array}$ \\
\hline $\begin{array}{l}\text { Commodity Price } \\
\text { Growth Volatility }\end{array}$ & $\begin{array}{r}2.262 \\
(1.95)^{*}\end{array}$ & $\begin{array}{r}1.718 \\
(2.39)^{* *}\end{array}$ & $\begin{array}{r}1.786 \\
(1.45)\end{array}$ & $\begin{array}{r}1.520 \\
(1.25)\end{array}$ & $\begin{array}{l}-0.443 \\
(1.05)\end{array}$ & $\begin{array}{r}6.069 \\
(0.22)\end{array}$ \\
\hline Change in Credit/GDP & & & $\begin{array}{r}0.680 \\
(0.81)\end{array}$ & $\begin{array}{r}0.992 \\
(1.02)\end{array}$ & $\begin{array}{r}0.374 \\
(0.56)\end{array}$ & $\begin{array}{r}6.533 \\
(1.08)\end{array}$ \\
\hline M2/Reserves & & & $\begin{array}{r}1.059 \\
(2.46)^{* *}\end{array}$ & $\begin{array}{r}1.133 \\
(2.67)^{* * *}\end{array}$ & $\begin{array}{r}0.546 \\
(2.34)^{* *}\end{array}$ & $\begin{array}{r}8.345 \\
(1.39)\end{array}$ \\
\hline Public Debt/GDP & & & $\begin{array}{r}0.705 \\
(1.23)\end{array}$ & $\begin{array}{r}0.176 \\
(0.30)\end{array}$ & $\begin{array}{r}0.110 \\
(0.34)\end{array}$ & $\begin{array}{r}3.540 \\
(0.56)\end{array}$ \\
\hline Inflation & & & $\begin{array}{r}1.174 \\
(1.61)\end{array}$ & $\begin{array}{r}1.495 \\
(1.71)^{*}\end{array}$ & $\begin{array}{r}0.791 \\
(1.38)\end{array}$ & $\begin{array}{r}9.615 \\
(1.33)\end{array}$ \\
\hline Net Capital Inflows/GDP & & & & $\begin{array}{r}0.982 \\
(2.23)^{* *}\end{array}$ & $\begin{array}{r}0.322 \\
(0.66)\end{array}$ & $\begin{array}{r}5.672 \\
(1.11)\end{array}$ \\
\hline Foreign Aid/GNI & & & & $\begin{array}{r}2.059 \\
(3.14)^{* * *}\end{array}$ & $\begin{array}{r}0.442 \\
(1.24)\end{array}$ & $\begin{array}{r}9.878 \\
(1.53)\end{array}$ \\
\hline Trade Openness & & & & $\begin{array}{r}-2.451 \\
(2.52)^{* *} \\
\end{array}$ & $\begin{array}{l}-0.802 \\
(1.82)^{*}\end{array}$ & $\begin{array}{r}-14.357 \\
(0.87)\end{array}$ \\
\hline \multicolumn{7}{|l|}{ Effect Size } \\
\hline Commodity Price Growth & -0.27 & -0.44 & -0.35 & -0.44 & -0.39 & -0.90 \\
\hline Volatility & 1.00 & 0.76 & 0.79 & 0.67 & -0.20 & 1.39 \\
\hline Change in Credit/GDP & & & 0.30 & 0.44 & 0.17 & 1.50 \\
\hline M2/Reserves & & & 0.47 & 0.50 & 0.24 & 1.92 \\
\hline Public Debt/GDP & & & 0.31 & 0.08 & 0.05 & 0.81 \\
\hline Inflation & & & 0.52 & 0.66 & 0.35 & 2.21 \\
\hline Net Capital Inflows/GDP & & & & 0.43 & 0.14 & 1.30 \\
\hline Foreign Aid/GNI & & & & 0.91 & 0.20 & 2.27 \\
\hline Trade Openness & & & & -1.09 & -0.36 & -3.30 \\
\hline \multicolumn{7}{|l|}{ Additional Covariate Groups } \\
\hline Deposit Insurance \& Crisis Dummies & $x$ & $x$ & $x$ & $x$ & $\times$ & $x$ \\
\hline 10-yr US Treasury Rate eoy & $x$ & $x$ & $x$ & $x$ & $x$ & $x$ \\
\hline Banking System & & $\times$ & $\times$ & $\times$ & $\times$ & $x$ \\
\hline Macro Fundamentals & & & $\times$ & $\times$ & $\times$ & $x$ \\
\hline LogL & -148.67 & -144.02 & -135.60 & -127.94 & -141.75 & -84.16 \\
\hline AUROC & 0.794 & 0.819 & 0.857 & 0.879 & 0.828 & 0.737 \\
\hline se(AUROC) & 0.029 & 0.026 & 0.025 & 0.025 & 0.030 & 0.042 \\
\hline ROC Comparison & & (2) vs (1) & (3) vs (1) & (4) vs (3) & (5) vs (4) & (6) vs (4) \\
\hline ROC Comp $p$-value & & 0.202 & 0.006 & 0.132 & 0.009 & 0.012 \\
\hline Wald $\chi^{2}(\mathrm{FE})$ & 9.93 & 13.90 & 40.26 & 70.80 & & \\
\hline Wald $p$-value & 0.127 & 0.084 & 0.000 & 0.000 & & \\
\hline
\end{tabular}

Notes: The results in this table are derived from commodity price growth and volatility variables constructed from country-specific weights based on mean commodity exports/GDP (instead of mean net export/GDP in Table 1 of the main text). The sample covers 35 banking crises in 60 (column (7): 29) countries, with 1,550 (804) observations. All results here are the economic magnitudes for a one standard deviation increase in the explanatory variable, expressed in percent. The 'Effect Size' section reports the associated effect of a 1sd increase in the covariate relative to the unconditional propensity of a crisis $(2.2 \%$ and $4.3 \%$ for the full and Logit FE samples, respectively) - this is helpful to compare results in the RE-Mundlak Logit and Pooled Logit models on the one hand and the Logit FE model on the other (with vastly differing unconditional crisis propensity). $\ddagger$ Due to the parsimony of the estimation equation we could not obtain standard errors for the marginal effects of these models via the Delta method. 
Table B-5: Main Results using annual net commodity exports/GDP as weights - Economic Magnitudes

\begin{tabular}{|c|c|c|c|c|c|c|}
\hline \multirow[b]{2}{*}{$\begin{array}{l}\text { Unconditional Crisis Probability } \\
\text { DV: Crisis Start Year }\end{array}$} & \multicolumn{4}{|c|}{ RE-Mundlak Logit } & \multirow{2}{*}{$\begin{array}{l}\text { Logit } \\
2.3 \% \\
(5)\end{array}$} & \multirow{2}{*}{$\begin{array}{c}\text { FE Logit } \\
4.3 \% \\
(6)\end{array}$} \\
\hline & $\begin{array}{l}2.3 \% \\
(1)\end{array}$ & $\begin{array}{l}2.3 \% \\
(2)\end{array}$ & $\begin{array}{c}2.3 \% \\
(3)\end{array}$ & $\begin{array}{l}2.3 \% \\
(4)\end{array}$ & & \\
\hline \multicolumn{7}{|c|}{ Selected Covariates (in percent, winsorized, $M A(3)$ transformed) } \\
\hline Commodity Price Growth & $\begin{array}{l}-0.346 \\
(1.18)\end{array}$ & $\begin{array}{l}-0.336 \\
(0.99)\end{array}$ & $\begin{array}{r}-0.319 \\
(1.15)\end{array}$ & $\begin{array}{l}-0.403 \\
(1.03)\end{array}$ & $\begin{array}{l}-0.375 \\
(1.15)\end{array}$ & $\begin{array}{l}-2.388 \\
(0.23)\end{array}$ \\
\hline $\begin{array}{l}\text { Commodity Price } \\
\text { Growth Volatility }\end{array}$ & $\begin{array}{r}0.488 \\
(0.25)\end{array}$ & $\begin{array}{r}0.890 \\
(0.41)\end{array}$ & $\begin{array}{r}0.566 \\
(0.28)\end{array}$ & $\begin{array}{r}0.250 \\
(0.17)\end{array}$ & $\begin{array}{r}0.033 \\
(0.09)\end{array}$ & $\begin{array}{r}-4.183 \\
(0.23)\end{array}$ \\
\hline Change in Credit/GDP & & & $\begin{array}{r}0.658 \\
(0.79)\end{array}$ & $\begin{array}{r}0.899 \\
(0.93)\end{array}$ & $\begin{array}{r}0.362 \\
(0.56)\end{array}$ & $\begin{array}{r}6.212 \\
(0.92)\end{array}$ \\
\hline M2/Reserves & & & $\begin{array}{r}1.041 \\
(2.46)^{* *}\end{array}$ & $\begin{array}{r}1.172 \\
(2.82)^{* * *}\end{array}$ & $\begin{array}{r}0.542 \\
(2.41)^{* *}\end{array}$ & $\begin{array}{r}8.932 \\
(1.06)\end{array}$ \\
\hline Public Debt/GDP & & & $\begin{array}{r}0.804 \\
(1.37)\end{array}$ & $\begin{array}{r}0.231 \\
(0.37)\end{array}$ & $\begin{array}{r}0.193 \\
(0.64)\end{array}$ & $\begin{array}{r}2.981 \\
(0.44)\end{array}$ \\
\hline Inflation & & & $\begin{array}{r}1.146 \\
(1.59)\end{array}$ & $\begin{array}{r}1.446 \\
(1.67)^{*}\end{array}$ & $\begin{array}{r}0.726 \\
(1.33)\end{array}$ & $\begin{array}{r}9.862 \\
(1.22)\end{array}$ \\
\hline Net Capital Inflows/GDP & & & & $\begin{array}{r}1.018 \\
(2.07)^{* *}\end{array}$ & $\begin{array}{r}0.287 \\
(0.57)\end{array}$ & $\begin{array}{r}5.406 \\
(0.99)\end{array}$ \\
\hline Foreign Aid/GNI & & & & $\begin{array}{r}2.107 \\
(2.88)^{* * *}\end{array}$ & $\begin{array}{r}0.433 \\
(1.22)\end{array}$ & $\begin{array}{r}10.991 \\
(1.49)\end{array}$ \\
\hline Trade Openness & & & & $\begin{array}{r}-2.067 \\
(2.15)^{* *}\end{array}$ & $\begin{array}{r}-0.767 \\
(1.75)^{*}\end{array}$ & $\begin{array}{r}-12.358 \\
(0.72)\end{array}$ \\
\hline \multicolumn{7}{|l|}{ Effect Size } \\
\hline Commodity Price Growth & -0.15 & -0.15 & -0.14 & -0.18 & -0.17 & -0.55 \\
\hline Volatility & 0.22 & 0.39 & 0.25 & 0.11 & 0.01 & -0.96 \\
\hline Change in Credit/GDP & & & 0.29 & 0.40 & 0.16 & 1.43 \\
\hline M2/Reserves & & & 0.46 & 0.52 & 0.24 & 2.05 \\
\hline Public Debt/GDP & & & 0.36 & 0.10 & 0.09 & 0.68 \\
\hline Inflation & & & 0.51 & 0.64 & 0.32 & 2.27 \\
\hline Net Capital Inflows/GDP & & & & 0.45 & 0.13 & 1.24 \\
\hline Foreign Aid/GNI & & & & 0.93 & 0.19 & 2.52 \\
\hline Trade Openness & & & & -0.92 & -0.34 & -2.84 \\
\hline \multicolumn{7}{|l|}{ Additional Covariate Groups } \\
\hline 10-yr US Treasury Rate eoy & $x$ & $x$ & $x$ & $x$ & $x$ & $x$ \\
\hline Deposit Insurance \& Crisis Dummies & $x$ & $x$ & $x$ & $x$ & $\times$ & $x$ \\
\hline Banking System & & $x$ & $x$ & $x$ & $\times$ & $x$ \\
\hline Macro Fundamentals & & & $\times$ & $\times$ & $\times$ & $x$ \\
\hline $\log L$ & -150.07 & -146.84 & -137.11 & -129.85 & -143.14 & -85.67 \\
\hline AUROC & 0.781 & 0.800 & 0.846 & 0.872 & 0.819 & 0.740 \\
\hline se(AUROC) & 0.030 & 0.030 & 0.027 & 0.026 & 0.032 & 0.041 \\
\hline ROC Comparison & & (2) vs (1) & (3) vs (1) & (4) vs (3) & (5) vs (4) & (6) vs (4) \\
\hline ROC Comp $p$-value & & 0.283 & 0.004 & 0.107 & 0.009 & 0.033 \\
\hline Wald $\chi^{2}(\mathrm{FE})$ & 9.43 & 6.34 & 31.99 & 61.27 & & \\
\hline Wald $p$-value & 0.151 & 0.610 & 0.002 & 0.000 & & \\
\hline
\end{tabular}

Notes: In this set of results the aggregate commodity prices are computed using annual net export/GDP weights instead of mean (Table 1) or base year (Table B-3) weights or mean export/GDP weights (Table B-4). All estimates shown are the economic magnitudes for a one standard deviation increase in the explanatory variable, expressed in percent. The 'Effect Size' section reports the associated effect of a 1sd increase in the covariate relative to the unconditional propensity of a crisis (2.3\% and $4.3 \%$ for the full and Logit FE samples, respectively). Sample: 35 banking crises in 60 (column (6): 29) countries, with 1,554 (808) observations. Absolute $t$-ratios in parentheses, based on standard errors computed via the Delta method from logit estimates (where in turn standard errors based on clustering at the country level). ${ }^{*},{ }^{* *}$ and ${ }^{* * *}$ indicate statistical significance at the $10 \%, 5 \%$ and $1 \%$ level, respectively. Additional covariate groups: 'Deposit Insurance \& Crisis Dummies' - fiscal crisis dummy, currency crisis dummy, deposit insurance dummy; 'Banking System' - liquidity, size; 'Macro Fundamentals' - real GDP growth.

\section{CInternational Monetary Fund. Not for Redistribution}

